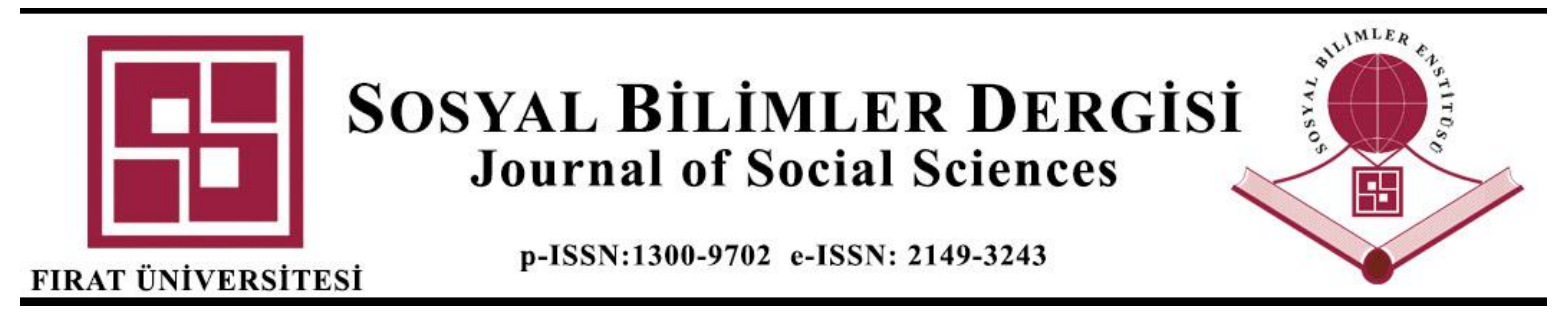

\title{
COĞRAFİ VE JEOPOLITTIK AÇIDAN GOLAN TEPELERİ
}

\author{
The Golan Heights in Geographical and Geopolitical Personality
}

\author{
Murat ÇINAR ${ }^{1}$ \\ ${ }^{1}$ Dr. Öğr. Üyesi, Karabük Üniversitesi Edebiyat Fakültesi Coğrafya Bölümü, Karabük, muratcinar7633@gmail.com, \\ orcid.org/0000-0002-7436-2114
}

Derleme/Review article

Makale Bilgisi
Geliş/Received:
26.07.2021
Kabul/Accepted:
06.12 .2021
DOI:
10.18069/firatsbed.974706

ÖZ

Golan Tepeleri, tarih boyunca Ortadoğu ile Akdeniz arasında önemli geçiş noktalarından birisi olmuştur. Bölge, sahip olduğu kaynaklar ve konumu itibariyle stratejik öneme sahiptir. İsrail, 1967'den önce Golan Tepeleri'nden Suriye ordusu tarafindan yapılan saldırılara maruz kalmaktaydı. Golan'ın, İsrail'in önemli şehirlerine yakınlı̆̆ 1 ciddi bir risk oluşturmaktaydı. Golan Tepeleri, 1967 yılında Altı Gün Savaşı sırasında İsrail ordusu tarafindan işgal edilmiştir. İsrail Meclisi 1981 yılında Golan'ı ilhak etme kararı almıştır. Uluslararası kamuoyu ve BM tarafindan mevcut durum işgal olarak kabul edilmektedir. Bölgenin, jeostratejik konumunun yanında zengin su kaynaklarına da sahip olması İsrail'e önemli avantajlar sağlamaktadır. Golan Tepeleri’ni kontrolü altında tutan İsrail önemli bir askeri üstünlüğe sahiptir. Ayrıca Golan Tepeleri, Yahudilerin dini açıdan kutsal saydığı bir bölgedir. Araştırma betimsel tarama modelinde gerçekleştirilmiştir. Çalışmada, İsrail-Arap Savaşları'nın yaşandığı önemli cephelerden birisi olan Golan Tepeleri'nin coğrafyası incelenmiş ve Anahtar Kelimeler $\quad$ jeopolitiği hakkında bilgiler verilmiştir. Çalışmada; Golan Tepeleri'nin sahip olduğu coğrafi
İsrail, Suriye, Golan, özellikler çerçevesinde stratejik önemini ortaya koymak amaçlanmıştır. Türkiye'de, Golan jeopolitik, coğrafya Tepeleri hakkında yapılan çalışma sayısı çok azdır. Bu çalışma ile ayrıca bölge hakkında yapılacak çalışmalara ve literatüre katkıda bulunmak amaçlanmıștır.

Keywords
Israel, Syria, Golan,
geopolitics, geography

\section{ABSTRACT}

The Golan Heights has been one of the important transit points between the Middle East and geopolitics, geography

the Mediterranean throughout history. The region has strategic importance due to its resources and location. Before 1967, Israel was subject to attacks by the Syrian army from the Golan Heights. The proximity of the Golan to Israel's major cities posed a serious risk. The Golan Heights was occupied by the Israeli army during the Six-Day War in 1967. The Israeli Assembly decided to annex the Golan in 1981. The current situation is accepted as an occupation by the international community and the UN. The fact that the region has rich water resources besides its geostrategic location provides significant advantages to Israel. Israel, which controls the Golan Heights, has a significant military advantage. In addition, the Golan Heights is a region that Jews consider religiously sacred. The research was carried out in the descriptive survey model. In the study, the geography of the Golan Heights, one of the important fronts of the Israeli-Arab Wars, was examined and information was given about its geopolitics. In the study; It is aimed to reveal the strategic importance of the Golan Heights within the framework of its geographical features. There are very few studies on the Golan Heights in Turkey. With this study, it is also aimed to contribute to the studies and literature about the region.

Atıf/Citation: Çınar, M. (2022). Coğrafi ve Jeopolitik Açıdan Golan Tepeleri. Fırat Üniversitesi Sosyal Bilimler Dergisi, 32, 1(19-36).

Sorumlu yazar/Corresponding author: Murat ÇINAR, muratcinar7633@gmail.com 


\section{Giriş}

Jeopolitik, stratejik konumlara ve doğal kaynaklara erişim üzerindeki büyük güç rekabeti olarak tanımlanmaktadır. Jeopolitik, coğrafya, güç ve uluslararası ilişkiler arasındaki ilişskilerle ilgili akademik bir disiplin olarak kabul edilir (Overland, 2015). Alman jeopolitikçi Haushofer jeopolitiği "devletin coğrafi bilinci" olarak tanımlamaktadır. Spykman'a göre jeopolitik, öncelikli olarak coğrafi konumun özelliklerine bağlı olarak devletin güvenliğine ilişkin meseleleri araştırmakla yükümlüdür (Hasanov, 2010). 20. Yüzyıla girilirken, "her şeyi açıklayan tek bir şey" olarak ortaya konmaya çalışılan jeopolitik, haritayla yani coğrafyayla başlamaktadır. Ancak sadece coğrafya ile sınırlı kalmamaktadır (Granieri, 2015).

Jeopolitik, coğrafi mekânı politika yaparken kullanma sanatıdır. Coğrafi mekanlar, politika yapan sanatçının enstrümanlarıdır. Jeopolitik statik olmaktan öte dinamik bir özellik gösterir. Coğrafi özelliklerin yanında küresel ve bölgesel çapta meydana gelen teknolojik ve ekonomik gelişmeler doğurduğu sonuçlar itibariyle jeopolitik üzerinde önemli bir etkiye sahiptir. Jeopolitik, karar verici aktörlerin politik tercihlerinde önemli bir rehber görevi görmektedir. Coğrafya, siyasi olayları incelemek için mekânsal farkındalık geliştirir. Coğrafya birçok disiplinde olmayan mekânsal farkındalıklara geniş bir bakış açısı ile bakmamızı sağlamaktadır. Coğrafya, olayların temelinde dünyamızın karşılıklı bağımlılığını, konum, yer, hareket, bölge ve insan-çevre etkileşimleriyle bağlantısını inceleyerek olayları farklı boyutları ile analiz etmemize imkân verir. Geçmişte yaşananlar, coğrafya sayesinde tarihi bir bağlama oturtulur. Tarihte olanların neden, ne zaman ve nasıl olduğunu görmemize yardımcı olur. Giderek birbirine bağımlı hale gelen dünyamızda olayların neden sonuç iliş̧isini bilimsel şekilde anlamlandırmak ve anlayabilmek için coğrafyayı etkin bir şekilde kullanmak önemli bir zarurettir.

Coğrafya kaderdir sözü ile betimlenen inanç, Ortadoğu'da yadsınamaz bir gerçekliktir. Ortadoğu sahip olduğu coğrafi konum ve potansiyelleri ile geçmişten bugüne politik, kültürel, sosyal, ekonomik ve askeri yapıları biçimlendirmede önemli rol oynamıştır. Ortadoğu, tarih boyunca farklı güç merkezlerinin çıkarları için mücadele ettiği önemli bir mekân olmuştur. Ortadoğu küresel güç merkezleri arasındaki mücadeleyi ve bu mücadele sırasında oluşan dengeyi etkileyecek bir öneme sahiptir. Ülkeler toprak bütünlüklerini, iç ve diş güvenliklerini, egemenliklerini tehditlere karşı korumak amacıyla coğrafi konumlarının avantajlarından yararlanarak politikalar geliştirirken, coğrafi açıdan dezavantajlı konumda bulunan ülkeler (örneğin İsrail) ise bu durumlarını avantaja dönüştürmek amacıyla farklı politikalar izlemişlerdir. Bu politikaların sonucu olarak Ortadoğu bugüne kadar silahlanmanın ve savaşların yegâne alanı olmuştur. Sahip olduğu coğrafi özellikler sayesinde yüzyıllarca farklı uygarlıkların yaşam alanı olan Ortadoğu bugün de birçok ülkeye ev sahipliği yapmaktadır. Bu bölge tarih boyunca kan ve göz yaşının değişmez adresi olmuştur. Bu gözyaşı Osmanlı Barış1 (Pax Ottomana) olarak adlandırılan dönemde dinmiş olsa da Osmanlı Devleti'nin bölgedeki egemenliğinin sona ermesi ile bu bölgeyi kan ve göz yaşı tekrar esir almıştır. Birinci ve İkinci Dünya Savaşı ve Soğuk Savaş dönemlerinde Ortadoğu önemli bir mücadele alanı olmuş bu durum bölgenin kaderini etkilemiştir. Soğuk Savaş’ın sona ermesinden bugüne kadar Ortadoğu'da küresel sonuçlar doğuran birçok toplumsal, askeri, ekonomik, siyasi sorunlar yaşanmıştır.

Golan Tepeleri, 1967 Altı Gün Savaşı'nda İsrail tarafından işgal edilen Suriye'ye ait kayalık bir platodur. Uluslararası toplum Golan Tepeleri'ni resmi Suriye toprakları olarak kabul etmekte ve İsrail'in askeri işgalini reddetmektedir (Zieve , 2021). 1 Eylül 1967 tarihinde açıklanan Hartum Kararı, Altı Gün Savaşı sonrası Sudan'ın başkenti Hartum'da toplanan Arap Birliği Zirvesi'nin sonunda yayınlandı. Bu zirvede alınan Karar, "Üç Hayır" olarak bilinen sloganıyla ünlüdür; "İsrail'le barışa hayır, İsrail'i tanımaya hayır, İsrail'le müzakereye hayır!". Bu "Üç Hayır" deklarasyonu, aynı zamanda "Hartum Deklarasyonu" olarak da Arap dünyasının ortak tavrı olarak tarihe geçmiştir. Ancak bu konuda sergilenen resmi tavır, perde arkasında bazı ilişkilerin kurulmasına engel teşkil etmemiştir. Gizli ilişkilerin kurulmasında ise özellikle ABD'nin İsrail'i himaye ve meşrulaştırma çabaları sebebiyle Arap dünyası üzerindeki baskılarının etkisi olmuştur (Varol, 2021).

1981'de İsrail Meclisi (Knesset), İsrail yasalarının Golan Tepeleri'nde uygulanmasını içeren bir yasayı kabul etmiştir. Bu yasa kabul edilmeden önce Golan Tepeleri askeri yönetim altındaydı. İsrail, 1981 Yasası ile de Golan Tepeleri'ni ilhak etmiştir. Buna karşılık Birleşmiş Milletler Güvenlik Konseyi, İsrail'in toprak statüsünü değiştirme eylemlerini kınayan ve bu yasayı "geçersiz ve uluslararası hukuki etkisi olmayan" bir yasa olarak ilan eden 497 Sayılı Kararı'nı oybirliğiyle kabul etmiştir. Bu kararla BM, Golan Tepelerini işgal altındaki bir bölge olarak kabul etmektedir. 2019'te ABD, Golan Tepeleri'ni İsrail egemen bölgesi olarak tanıyan tek devlet olurken, uluslararası toplumun geri kalanı Golan'ı Suriye'nin İsrail'in işgali altındaki bir bölge olarak kabul etmektedir (Aji, 2021). 


\section{2. Çalıșmanın Amacı}

$\mathrm{Bu}$ çalışmada, Ortadoğu siyasetinin en önemli vakalarından olan İsrail-Arap Savaşlarının yaşandığı coğrafi mekanlardan birisi olan Golan Tepeleri'nin coğrafyası ve jeopolitiği incelenmiştir. Çalışmada; Suriye egemenliğinde olan ancak 1967 yılında Altı Gün Savaşı sırasında İsrail tarafından işgal edilen ve daha sonra ilhak edildiği açıklanan Golan Tepeleri'nin sahip olduğu coğrafi özellikler belirlenerek bu özelliklerin Suriye ve İsrail açısından jeopolitik değerlendirmesinin yapılması amaçlanmışıtır. Bu çalışmanın, ilgili alanyazında yapılacak çalışmalara katkı sağlayacağı düşünülmektedir. Bu çalışmayı önemli kılan Golan Tepeleri’nin işgaline coğrafi ve jeopolitik açıdan toplu bir bakış açısı sunması ve daha önce bu biçimde konunun ele alınmamış olmasıdır.

\section{Materyal ve Metot}

Araştırma betimsel tarama modelinde gerçekleştirilmiştir. Arseven (2001, s. 103); bu tip araştırmalar, olgular hakkında sistemli ve düzenli bilgiler elde edilerek yapılır. Betimleyici bir araştırmada herhangi bir durumun varlığı veya yokluğu ortaya koyulmaya çalışılır. Betimleyici araştırmaların sonuçları, tablo, grafikler yorumlanır ve değişkenler arasında korelasyonun varlığı veya yokluğu saptanır, biçiminde açıklamıştır. Çalışmanın materyalinde alan yazın taramasının çalışmayı güçlendireceği bilindiği için yerli ve yabancı kaynaklar detaylı olarak taranarak Golan Tepeleri’nin işgalinde etkili olan faktörler belirlenmiştir. Çalışmada, yazar tarafından hazırlananların yanı sıra farklı kaynaklardan da alınan kartografik malzemelerden yararlanılmıştır.

\section{Golan Tepeleri'nin Yeryüzü Şekilleri}

Golan Tepeleri, İsrail'in kuzeydoğusundaki konumu ve zengin su kaynakları nedeniyle stratejik öneme sahip olan bir yükseltidir. Bazaltla kaplı olan Golan Tepeleri, $32^{\circ} 40^{\prime}-33^{\circ} 15^{\prime} \mathrm{N}, 35^{\circ} 35^{\prime}-35^{\circ} 50^{\prime} \mathrm{D}$ matematik konumunda bulunmaktadır. Golan, coğrafi olarak batıda Ürdün Nehri ve Taberiye Gölü, kuzeyde Hermon Dağı, doğuda Yermuk Nehrinin ana kollarından biri olan ve Golan Tepeleri'nin topoğrafik doğu sınırını oluşturan mevsimsel Wadi El-Ruqqād ve güneyde Yermuk Nehri ile sınırlanmıştır (Britannica, 2021). Suriye, Ürdün, Lübnan ve İsrail Devletlerinin sınıllarının kesiştiği bölgede bulunan tepeler kuzeydoğu komşularının sınırlarını belirlemektedir (Şekil 1). Plato görünümüne sahip olan Golan'ın kuzey-güney uzunluğu yaklaşık 65 kilometredir ve doğu-batı genişliği 12 ila 25 kilometre arasında değişmektedir (Marshall, 2002). Golan Tepeleri, Taberiye Gölü’nün 2 km kuzeydoğu ve doğusunda, kuzeydeki Hermon antiklinali ile güneydeki Ajlun antiklinali arasında bulunmaktadır. Golan'ın kuzey kesimindeki yükseklikler yaklaşık 1200 m'ye ulaşmaktadır. Volkanik plato bu bölgeden hızla batıya doğru Hula Vadisi'nde deniz seviyesinden $70 \mathrm{~m}$ yüksekliğe kadar iner ve sonrasında yavaş yavaş 340 m yüksekliğe kadar çıkmaktadır (Mor, 1993).

Lübnan-İsrail-Suriye sınır bölgesinde Golan'ın yüksekliği Hermon Dağı'nda 2.814 metre, güneydeki Yermuk Nehri boyunca ortalama yaklaşık 400 metre yüksekliğe sahiptir. Golan Tepeleri'nin güneybatı köşesindeki Taberiye Gölü (Kinneret Gölü veya Celile Denizi olarak da bilinir) deniz seviyesinin 200 metre altındadır (Marshall, 2002).Topoğrafik olarak bölge volkanik arazidir ve batı ucunda, Ürdün Vadisi'nin üst kısmına ve Taberiye Gölü’ne inen dik uçurumlarla karakterize görünümdedir. Bölgedeki bazaltlar ve diğer volkanik kayaçlar Pliyosen-Pleistosen döneminden kalmıştır (Mor, 1986). Bu bölge volkanik mostralarla serpiştirilmiş dalgalı kırsal bir bölgedir. Bu dalgalanmaların bir kısmı platonun hâkim özellikleri haline gelmiştir. Zeminin geri kalanı bazalt kaya çıkıntıları, bazı bitki örtüsü ve ağaçlarla birlikte lav yamaları ile karakterizedir. Hem kışın hem de yazın kuzeybatıdan güneydoğuya yayla boyunca bazen firtına kuvvetine yükselen serin bir esinti bu bölge üzerinde etkilidir. Bazalt türevi toprakların çoğu, Taberiye Gölü'nün doğusunda ve Golan Tepeleri’nde yoğunlaşmıştır (Şekil 2). Doğu Taberiye, güneybatıya doğru eğimli bir yayla ve havza sisteminden oluşmaktadır (Fıvaz, 1980).

Platolar, üst Pliyosen-alt Pleistosen'de en son bazalt akıntıları ile kaplanmış eğimli bloklardan oluşmuştur. Miyosen'den gelen eski bazalt akışları, kıtasal Neojen oluşumları ile kapak bazaltından ayrılır (Singer, 2007). Platoların kabarıklı̆ğ hafif, eğimleri orta düzeydedir. Bu bölgede erozyonun ana etkisi, bazaltın yatay katmanlarının aşındırılması şeklinde olmuştur. Kayanın nispeten homojen yapısı nedeniyle, peyzaj derinlemesine kazılmamıştır ve drenaj ağı sadece yüzeyseldir. Bölge küçük akarsular, uzun yaylalar, sığ sırtlar halinde parçalara ayrılmıştır. Sadece bazaltın tamamen kalktı̆̆ı yerlerde, açıkta kalan yumuşak Neojen çökellerinde daha derin vadiler oyulmuştur. Ürdün Vadisi'ne doğru akışa geçen akarsular dik eğim nedeniyle derin bir şekilde aşındırma yapmıştır. Bu durum platoların üst kısımlarıyla çelişen bir fizyografi oluşturur (Amiran, 1970). 


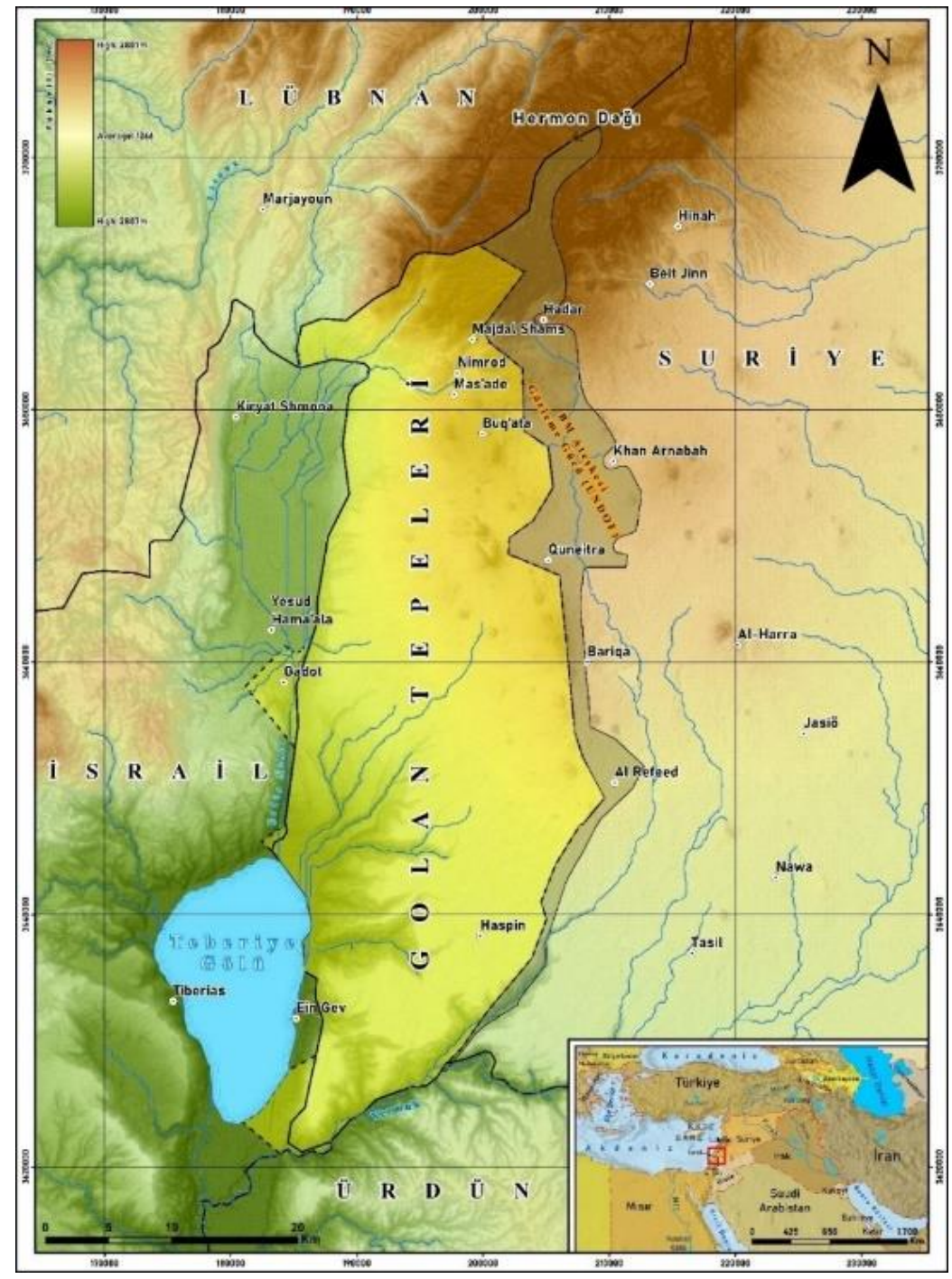

Şekil 1. Golan Tepeleri'nin fiziki haritası.

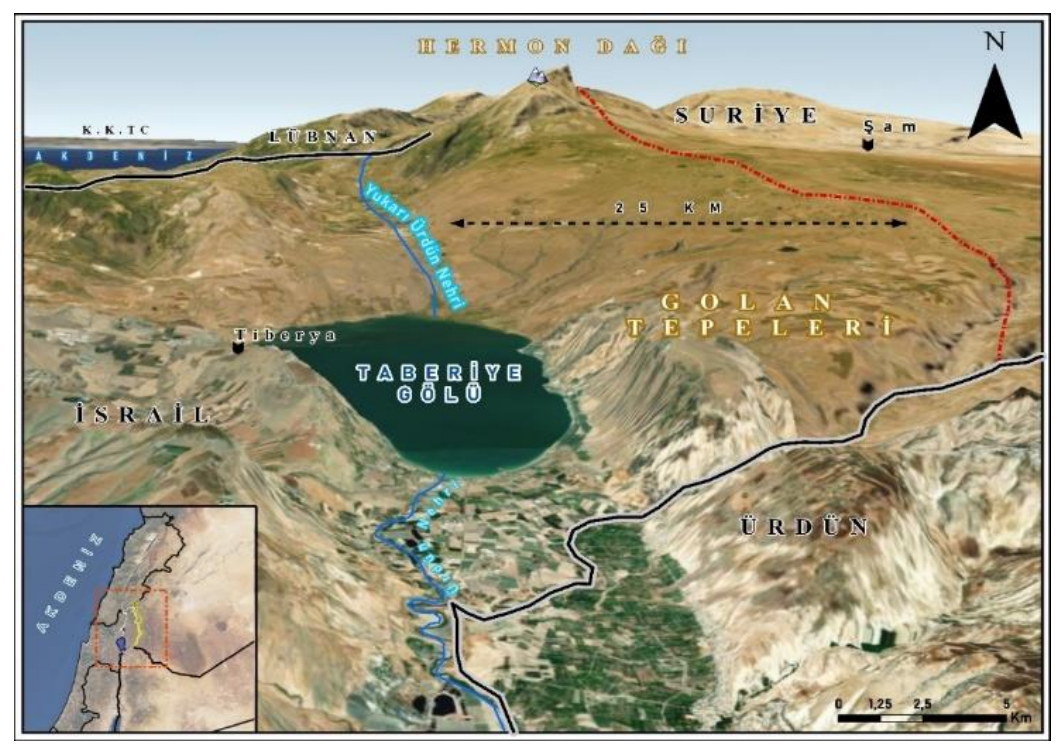

Şekil 2. Golan Tepeleri'nin üç boyutlu haritası. 
Golan Tepeleri, Ürdün Nehri'nin ikiye ayırdığı iki farkı jeolojik (Golan Tepeleri ve Hermon Dağı yamaçları) alandan oluşmaktadır (Şekil 1). Hermon Dağı silsilesi çoğunlukla kireçtaşıdır buna karşın Golan Tepeleri ise çoğunlukla bazalt ve diğer volkanik kaya türlerine sahiptir. Golan Tepeleri, Ürdün Nehri ile Taberiye Gölü (Rift Vadisi'nin Suriye bölümü) ve güneyde Yermuk Nehri'ne doğru bir plato oluşturur. Platoda, bazen çok derin vadilerden geçen ve batıya Ürdün'e veya göle akan bir dizi mevsimsel dere bulunmaktadır (Şekil 3). Golan Tepeleri üç bölgeye ayrılır. Bunlar Kuzey Bölge (Nahals Sa'ar ve Gilabon arasında), Orta Bölge (Nahals Gilabon ve Dilayot arasında) ve Güney Bölge (Nahal Dilayot ve Yermuk Vadisi arasında)'dir (Jewish Virtual Library, 2021). Hermon Dağı bölgesi ve Kuzey Golan, Güney Golan'ın ortalama yağışının iki katı yağışa sahiptir. Hidrolojik olarak, İsrail'in su gereksinimin önemli bir kısmını sağlayan Taberiye Gölü (Şekil 2), Golan havzasında yer almaktadır (Rimmer ve Givati, 2014).

Golan Tepeleri üzerinde bulunan, deniz seviyesinden 2814 metre yüksekliğe ulaşan Hermon Dağı, Suriye ve İsrail'in en yüksek dağıdır (CIA, 2021). Hermon kelimesi "Kutsanmış bir yer" anlamına gelmektedir (Bible Charts, 2021). Dağ, her biri yaklaşık aynı yükseklikte üç ayrı zirveye sahiptir. Hermon Dağı'nın çoğu, suda çözünürlüğ̈̈ yüksek olan Jura kireçtaşından oluşmuştur. Bu özelliği nedeniyle, yüksek yağışlar neticesinde Hermon Dağı'nda gelişmiş karstik manzaralar ortaya çıkmıştır (Lib. Cet., 2021) .

\section{Golan Tepeleri'nin Hidrografyası}

21. Yüzyılda dünyanın karşılaştı̆̆ temel sorunlardan birisi su kıtlı̆̆ıdır. Su kullanımı, nüfus artış hızından daha fazla artmaktadır ve küresel su kıtllı̆ı olmamasına karşı dünya üzerinde farklı bölgelerde kronik olarak su sıkıntısı çekilmektedir. Su kıtlığı hem doğal hem de insan kaynaklı bir sorundur. Sınır ötesi su kaynaklarını paylaşan ülkeler arasındaki barışçl iş birliğinin ilgili ülkelerin güvenliği ve barışı ile doğrudan ilişkili olduğunu göstermektedir. Buna karşın aktif su iş birliğinin gerçekleşmediği durumlarda paylaşıma ortak olan ülkeler arasında savaş riski ortaya çıkmaktadır. 148 ülkede 200'den fazla paylaşılan nehir havzasında sınır ötesi su ilişkileri incelendikten sonra hazırlanan "Water Cooperation for a Secure World" adlı rapora göre Ortadoğu'daki ülkeler, bölgesel iş birliğine uzak durdukları için muhtemel bir savaş riskiyle karşı karşıya bulunmaktadır (Waslekar...vd., 2013). Ortadoğu'da su önemli bir stratejik kaynak ve politik bir konudur. 2025 yılına kadar, Arap yarımadası ülkeleri doğal olarak kullanabilecekleri su miktarının iki katından fazlasını kullanacağı tahmin edilmektedir (Sutherland, 2021). Bölgede, Ürdün, İsrail, Filistin, Suriye, Irak, Lübnan ve Körfez Ülkelerinin tümü su konusunda önemli endişeler yaşamaktadırlar. Sınırlı arz ile ekonomik kalkınma ve artan nüfusun ihtiyaçlarını karşılamak için hızla artan su talebi arasında yapısal bir dengesizlik bulunmaktadır. Arap Ligi tarafindan hazırlanan bir rapora göre, Arap ülkelerinin üçte ikisinde kıtllğın eşiği olan kişi başına yılda 1.000 metreküpten az su bulunmaktadır. 500 metreküpte durum kritik hale gelmektedir. 100 metreküpün altında tuzdan arındırma veya kullanılmış suyun geri dönüşümü gibi istisnai önlemlere ihtiyaç bulunmaktadır. Körfez Ülkeleri, Ürdün, İsrail ve Filistin'de su miktarı bugün kritik sınır olan 500 metreküpün altında bulunmaktadır (Chesnot, 2021).

Golan Tepeleri’nin en önemli özelliği bölgedeki nehirlere kaynaklık etmesidir. Suriye, Lübnan ve Ürdün bu bölgeden kaynaklarını alan nehirlere sahiplerdir (Şekil 3). Golan Tepeleri coğrafi olarak, İsrail'in su ihtiyacının önemli bir kısmını karşılayan Taberiye Gölü’ne kadar uzanmaktadır. İsrail'in Golan Tepeleri'ndeki işgalini sürdürmesinin en önemli nedenlerinden birisi önümüzdeki yıllarda su kaynaklarına daha fazla ihtiyaç duymasidır.

Taberiye Gölü'nü besleyen sular, kaynağını kuzeydoğu bölgesine hâkim olan Golan Tepeleri’nden almaktadır. Ürdün (Şeria) Nehri, gölün ana kaynağını oluşturmaktadır (Şekil 4). Ürdün Nehri kaynağını üç büyük dereden almaktadır. Bunlar Dan, Baniyas ve Hasbani dereleridir. Hasbani, Ürdün (Şeria) Nehri’nin Lübnan'da doğan ve daha sonra İsrail'e geçen koludur. Ürdün Nehri'nin diğer kolları ise 1967 öncesi İsrail sınırları içinde yer alan Dan ve 1967 yılındaki Altı Gün Savaşı'ndan sonra İsrail'in işgal ettiği Golan Tepeleri'nde yer alan Banyas koludur. Ürdün Nehri İsrail'in temel yerüstü su kaynağı durumundadır ve yıllık ortalama akımı oldukça fazladır. Bu toplama mevsimlik küçük derelerin katkısının yanı sıra Suriye'den kaynaklanan Yermuk gibi büyük kollar da dahildir (Pamukçu, 2000). İsrail sınırları içinde birleşen Dan, Hasbani ve Banyas kolları 1950'li yıllarda bölgeye yerleşen İsrailliler tarafından kurutularak tarıma açılan Huleh bataklıklarını geçerek Taberiye Gölü’ne dökülmektedir. İsrail, "Ulusal Su Taşıııcısı” adındaki ana su yapısı ile bu gölden aldığı suları nüfusun yoğun olduğu kıyı bölgeleri ile Necef çölündeki tarımsal alanlara taşımaktadır. Hasbani kolunun akımı kurak ve yarı kurak bir iklimde yer almasından dolayı, bölgedeki diğer nehirler gibi, yıldan yıla büyük değişiklikler göstermektedir. Hasbani kolunun yıllık akımı 52 ile 236 milyon metreküp arasında değişmektedir (UNU, 2021). 


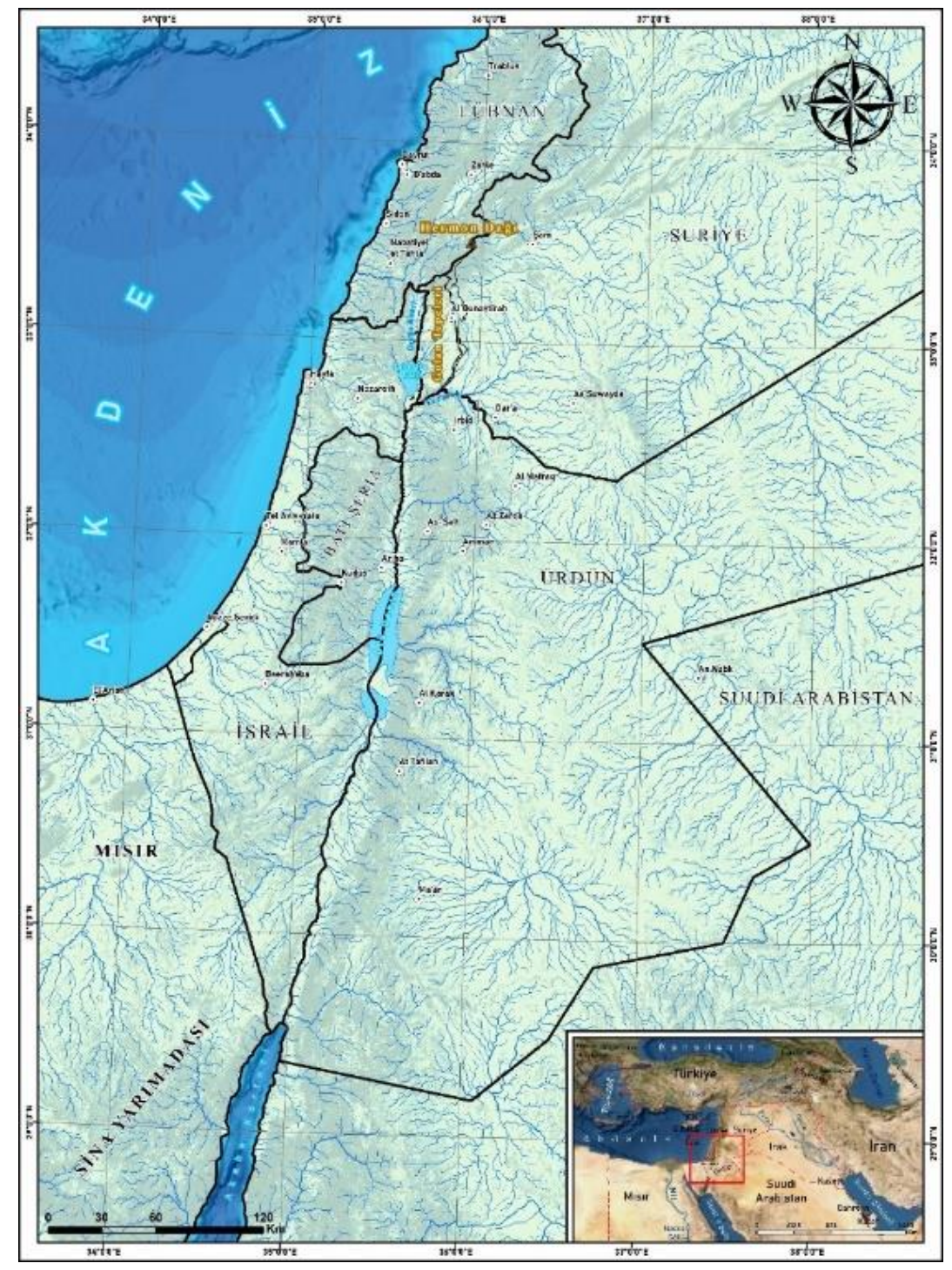

Şekil 3. İsrail ve komşu ülkelerin hidrografya haritası.

Taberiye Gölü, Ölü Deniz yarığının kuzeyinde yer almaktadır. Su toplama havzası yaklaşık 2.730 km²'lik bir alana yayılmaktadır. Havza, Hermon Dağı'nın batı yamaçları, Lübnan Dağları'nın güneydoğu yamaçları, İyun Vadisi, Doğu Taberiye, Golan Tepeleri ve Hula Vadisi'ni kapsamaktadır. Gölün yüzölçümü $166,7 \mathrm{~km}^{2}$ ve maksimum derinliği yaklaşık 46 m'dir. Taberiye Gölü'nün ortalama derinliği ise yaklaşık 25 m'dir ve gölde maksimum seviyede depolanan su hacmi yaklaşık 4412 milyon $\mathrm{m}^{3}$ 'tür. Göl'de toplanan ortalama yıllık su miktarı yaklaşık 710 milyon m³'tür (IOLR, 2021). Taberiye Gölü (Kinneret-Galilee Gölü), Golan Tepeleri ile Galile Tepeleri arasında deniz seviyesinin -212 metre altında yer almaktadır. Bu seviye ile Taberiye Gölü topoğrafik yükseklik açısından dünyanın en düşük tatlı su gölüdür. Taberiye Gölü yaklaşık 53 km kıyıya sahip olup 8 km genişliğinde ve 21 km uzunluktadır (İsrail Dişişleri Bakanlığ 1 , 2021). Taberiye Gölü, İsrail'in en büyük tatlı su gölüdür ve ülkenin ana su deposu olarak hizmet vermektedir. Kıyıları boyunca bazı önemli tarihi ve dini yerlerin yanı sıra tarım toplulukları, balıkçılık ve turistik tesisler bulunmaktadır.

İsrail'in, Golan Tepeleri'nden çekilmesinin hidropolitik ve jeopolitik açıdan önemli kısıtları bulunmaktadır. Golan'da kurulan hakimiyet sayesinde Taberiye Gölü ile Banyas ve Yermuk Nehirleri'ni kontrol altında tutan İsrail, sadece askerî açıdan değil aynı zamanda su güvenliği açısından da gelecekte Golan'ı terk etmeden belirli güvenceler elde etmeye çalışacaktır. Bu bölgenin hidrojeopolitiğini belirleyen en önemli unsur Golan Tepeleri'ne hâkim olmaktır (Yıldız, 2009). İsrail, su ihtiyacını dört farklı kaynaktan elde etmektedir. Bu kaynaklar yaklaşık \%36 ile Taberiye Gölü ve Ürdün Nehri'ne doğal olarak akan yağmur suyu, \%28 ile dağ akiferleri, \%14 ile kıyı akiferi ve \%23 ile geri dönüşüm şeklindedir. İsrail, 1967'de Batı Şeria ve Golan 
Tepeleri'nin kontrolünü ele geçirerek mevcut su ihtiyacını karşılayacak kaynaklara sahip olmuştur. Taberiye (Kinneret-Galile) havzası, yaklaş1k 500 milyon $\mathrm{m}^{3}$ / y1l (ulusal üretimin\%27'si) üretimiyle İsrail'deki en büyük yeraltı suyu havzasıdır. Taberiye Gölü, alt havzaların yeraltı sularının doğal bir ortak çıkış bölgesidir. Alt havzaların hidrojeolojik birimleri yaşlı akiferleri içerir. Havza, kuzeydeki Hermon Dağı'ndan güneydeki Taberiye Gölü'ne kadar uzanır. Doğu sınırı, Ürdün havzası ile sinırlanan Golan bölgesindedir. Bu bölgeler doğrudan yağmur ve kar yağışı ile göl kaynağını oluşturmaktadır (Jewish Virtual Library, 2021). Hermon Dağ1, bölgenin en yüksek noktası olması itibariyle önemli su kaynaklarından birini oluşturur. Dünyanın en kurak bölgelerinden birisinde bulunmasına karşın yüksekliğinden dolayı önemli miktarda yağış alır. Hermon Dağı, yılın büyük bir bölümünde zirvelerinin üçünü de kaplayan kış ve ilkbahar kar yağışlarına sahiptir. Karla kaplı dağın batı ve güney kısımlarında eriyen kar suyu, arazideki gözeneklerine sızarak, dere ve nehirleri oluşturan dağın dibindeki kaynakları besler. Bu kaynaklar birleşerek Ürdün Nehri’ni oluştururken meydana gelen yüzey akışları, üzüm bağları, çam, meşe ve kavak ağaçlarının bol olduğu kar çizgisinin altındaki bölgelerde verimli bitkilerin yetişmesini kolaylaştırır (Auerbach ve Shmida, 1993).

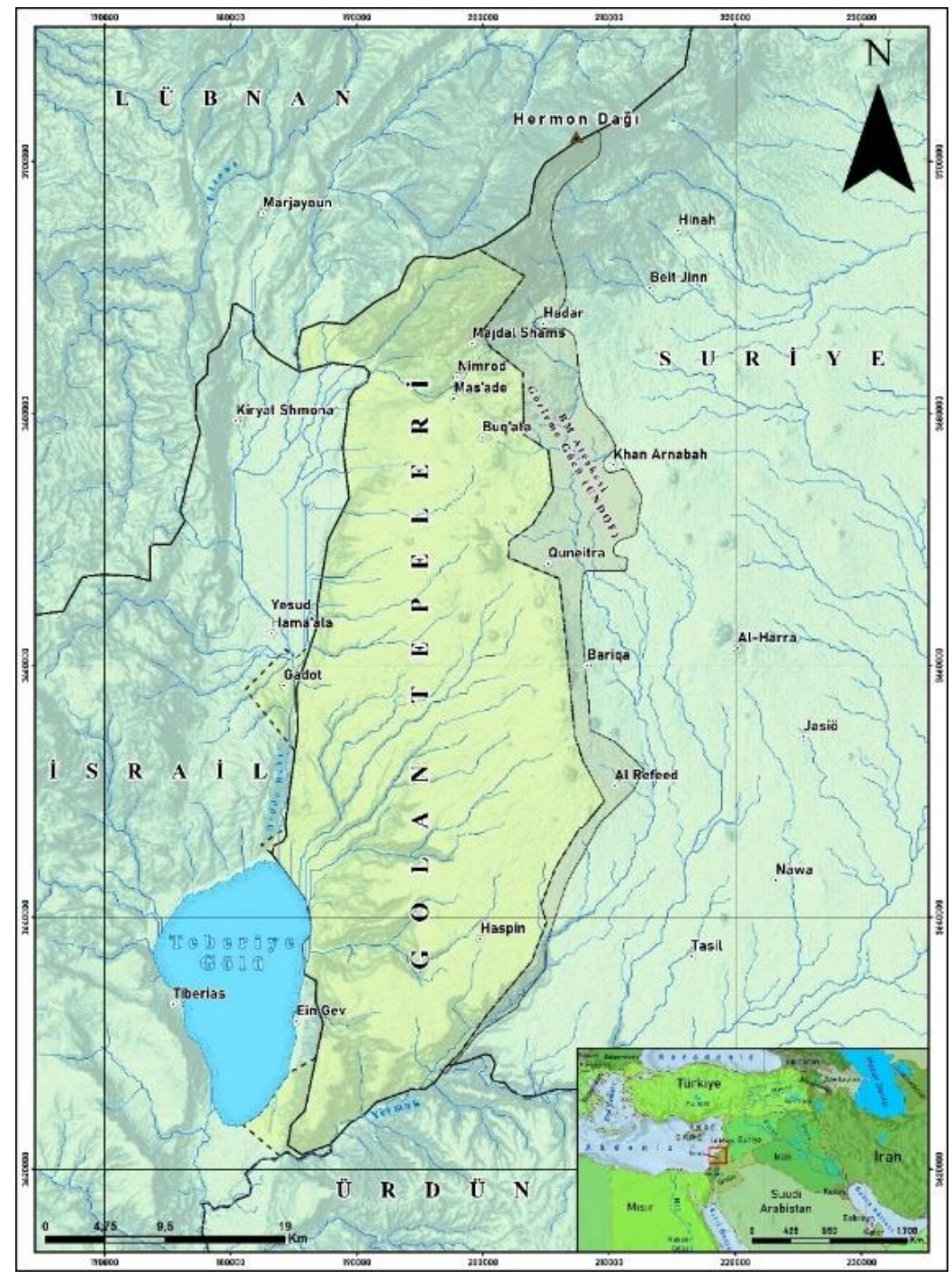

Şekil 4. Golan Tepeleri'nin hidrografya haritası.

Tarihsel süreç incelendiğinde 1964 yılında, Suriye ile İsrail arasında meydana gelen sınır çatışmalarının ana sebebi, Suriye ve Lübnan'ın, Banyas ve Hasbani kollarını Suriye'de doğan ve daha sonra Ürdün nehrine Taberiye Gölü'nün aşağısında katılan Yermuk Nehri'ne çevirme yönündeki planlarını gerçekleştirme çalışmalarına başlamalarıdır. İsrail, bu dönemde çalışma yapılan yerlere sınırdan ateş açmış ve savaş uçakları ile bombalamıştır (Kılıç, 2021). Su konusunda iş birliği yapılmaması, sonraki yıllarda Suriye ile İsrail 
arasındaki çatışmayı açıkça daha da şiddetlendirmiştir. İsrail Dışişleri Bakanı Sharrett'in günlüklerinde; 1967 Altı Gün Savaşı'nda işgal edilen bölgelerle ilgili siyasi kararların 1954 yılında daha erken bir zamanda alındığını belirtmiş̧ir (Rokach, 1980). 1967 Savaşı'na giden yolu açan olaylar, Johnston müzakerelerinin çökmesinden sonra üstlenilen tek taraflı su projeleriyle bağlantılıdır. Sınır çatışmaları hidrolik tesisleri hedef almaya başlamıştır (UNSC, 1960). Böylece 1962'de Suriye, BM Güvenlik Konseyi'ne yaptı̆̆ı resmi bir şikâyette İsrail'in hidrolik projelerini "barış ve güvenliğe tehdit" olarak nitelendirmiş̧iir (UNSC, 1962). 1964 Arap Birliği toplantısında yer alan üyeler, Ürdün Nehri kollarının sularını yönlendirmeye de karar verdiklerinden İsrail, 1967 Ocak ve Haziran ayları arasında Suriye topraklarını bombalamayı yoğunlaştırırken Suriye ve Ürdün'deki hidrolik tesisleri hedef almıştır. 1967 yılında, Golan Tepeleri ve Yukarı Hermon Dağı'nın \%70'inin İsrail tarafından işgali, Yukarı Ürdün Nehri'nin bütünüyle ele geçirilmesiyle sonuçlanmıştır. Savaşın Suriye'ye giden su akışı üzerinde önemli bir etkisi olmuş ve mevcut hidrolojik seçenekleri değiştirmiştir. İsrail için en büyük jeopolitik kazanımlardan biri, kıyıdaş konumunun kısmen aşağı akıştan tamamen yukarı akışa doğru değişmesidir. İşgalin başlamasından bu yana İsrail'in suyunun \%60' Ürdün Nehri'nden de alınmıştır. Suriye'nin Yukarı Ürdün sularına erişimi reddedilmiş, böylece Banyas Nehri'nden 125 milyon metreküp yıllık su akışı ve Dan Nehri'nden de aynı miktarda 125 milyon metreküp su kaybedilmiştir. Suriye'nin Fırat Nehri (toplam su hacminin \%65'ini oluşturmaktadır) gibi diğer kaynaklara olan bağımlılığının oldukça yüksek olması dikkate alındığında, Banyas sularının ve Golan Tepeleri'nin ele geçirilmesi, toprak ve ulusal bütünlük açısından daha önemli ölçüde yüksek sembolik bir ağılık taşımaktadır. Savaş sonrasında Banyas ve Hasbani'nin suları hızla ulusal su taşıma sistemine yönlendirilmiş ve İsrail'in su açığının hafifletilmesi sağlanmıştır (Daoudy, 2008).

1968'de İsrail, Golan'ın su kaynaklarına erişim imkanını yalnızca kendisine veren 120 Sayılı askeri emirden başlayarak bir dizi yasa çıkardı. Bu yasalardan birinde, bir araziye sahip olmanın, arazinin üzerindeki veyahut altındaki suya da sahip olma hakkını sağlamadığı şeklinde bir hükmü getiriyordu. Bu türden yasalar, yaşamlarını sürdürmek için tarımla geçimini sağlayan yerel Arap çiftçiler üzerinde olumsuz sonuçlar doğurdu. Kaynağı kendi çiftlikleri içerisinde olmasına karşın suya olan erişimlerini kaybeden Arap çiftçiler, bunun yerine kendilerine yüksek fiyatlarla ve yalnızca düşük kotalar dahilinde su satan İsrail şirketlerinden su satın almak zorunda kaldılar (Agha, 2021). İsrail, Golan'ın su kaynaklarını kullanmanın yanı sıra, bölgedeki Suriyeli nüfusa karşı ayrımcı su politikaları uygulamış, Suriyelilere yüksek fiyatlardan su satmış ve buna rağmen satın almalarına izin verilen su miktarı için daha düşük kota koymuştur. Golan'da yasadışı ikametleri olan İsrailli yerleşimciler ölçüsüz suya erişimin keyfini çıkarırken, Suriye nüfusu ve arazinin hak sahipleri önemli kısıtlamalar yaşamaktadır. Tarımsal üretimi sürdürmek isteyen Suriyeli çiftçilerin erişimine izin verilen kaynaklar ise İsrailliler tarafindan gerçekleştirilen sondaj faaliyetleri ve su çıkarma çalışmaları sonucunda kurumaktadır (Marsad, 2021). Su maliyetlerinin yüksekliği tarımsal üretimde elde edilen kazancı azaltmaktadır. İsrail, önemli miktarda meyve ve sebzesini üretmek için Golan'dan aldığı sudan yararlanmaktadır. İsrail yerleşimlerinin su ihtiyacı "Ulusal Su Taşıyııı Boru Hattı” üzerinden karşılanmaktadır. Tarım arazilerini sulamak için ise Golan'dan elde ettiği suyu kullanmaktadır (Davis, Maks, ve Richardso, 1980). İsrail, bölgede çıkarılan su üzerinde oluşturmuş olduğu tekel sayesinde önemli kazançlar sağlamaktadır. "Eden Springs" gibi İsrailli şirketler, satı̧ıını yaptıkları suların "Golan Tepeleri’nin kalbindeki güzel ve doğal şelaleden" aktı̆̆ yönünde reklamlarını gururla yapmaktadır (Marsad, 2021). Daoudy (2008)'e göre; suyu bir kenara bırakan herhangi bir toprak yerleşimi veya nihai sınırları göz ardı eden herhangi bir su yerleşimi ve daha da önemlisi her iki konuyu da tam olarak ele almayan herhangi bir yerleşim başarısızlığa mahkumdur. Suriye ve İsrail yıllardır refahları ve güvenlikleri için hayati önem taşıyan konuları müzakere etmelerine karşın sorun henüz çözülmemiştir (Daoudy, 2008). Su, Arap-İsrail ihtilafında önemli bir konudur. İsrail eski başbakanı Ariel Şaron'a göre, su sorunu 1967 Altı Gün Savaşı'nın nedenlerinden biriydi. Ona göre Altı Gün Savaşı'nın Suriyelilerin İsrail'e su akışını engellemeye çalıştıkları için başladığını itiraf etmişsir. Bölge ülkeleri için su artık en önemli savaş sebebi olmuştur. İsrail ile 1979 barış anlaşmasını imzaladıktan sonra Mısır Cumhurbaşkanı Enver Sedat, ulusunun su kaynaklarını korumak dışında bir daha asla savaşa girmeyeceğini söylerken, Ürdün Kralı Hüseyin, suyu Yahudi devletiyle savaşa sürükleyebilecek tek neden olarak tanımlamıştır (Darwish, 2021). Su kaynaklarının Ortadoğu ülkeleri için önemi yadsınamaz bir gerçekliktir. İsrail'in güvenliğini gerekçe göstererek işgal ve sonrasında uluslararası hukuku ihlal ederek ilhak ettiği Golan Tepeleri’nin sahip olduğu su kaynakları bu yasadışı eylemlerin en önemli nedenlerinden birisidir.

\section{Golan Tepeleri'nin İklimi ve Bitki Örtüsü}

İsrail, yüzölçümü bakımından küçük bir ülke olmasına karşın farklı iklim kuşaklarına sahiptir. İsrail yaklaşık olarak $470 \mathrm{~km}$. uzunlukta ve en geniş noktada ise yaklaşık $135 \mathrm{~km}$. genişlikte bir ülkedir. Dağlar ve ovalar, verimli topraklar ve çöl genellikle birkaç saat uzaklıktadır (İsrail Dışişleri Bakanlı̆̆ı, 2021). İsrail, esas 
olarak ülkenin çeşitli topografyasından kaynaklanan çok çeşitli iklim ve bitki türlerine sahiptir (Şekil 5). İsrail genelinde ortalama yıllık sıcaklıklar rakıma ve konuma göre değişiklik göstermektedir. İsrail, 1lıman bölge ile tropikal bölge arasında, subtropikal bölge olarak nitelendirilen ekvatorun $29^{\circ}-33^{\circ}$ kuzeyinde yer almaktadır. İsrail'in kuzey ve kıyı bölgeleri, sıcak ve kurak yazlar ve serin, yağışlı kışlarla karakterize bir Akdeniz iklimine sahiptir. İsrail'in güney ve doğu bölgeleri kurak bir iklim ile karakterizedir. Yoğun kar yağıșı, Hermon Dağı zirvesinde görülmektedir. Kar yağışları genellikle Aralık'tan Mart'a kadar karla kaplı olan Golan Tepeleri’nin yalnızca en kuzey kısmına düşer. Ülkenin diğer bölgelerinde kar yağışı nadiren görülür (Science Israel, 2021). İsrail'in işgali altında bulunan Hermon Dağı'nın güney yamaçlarında kayak merkezi bulunmaktadır. Bu dağın diğer tarafında Suriye ve Lübnan devletlerinin sınırları bulunmaktadır (Şekil 2; Popular Mechanics, 2021).

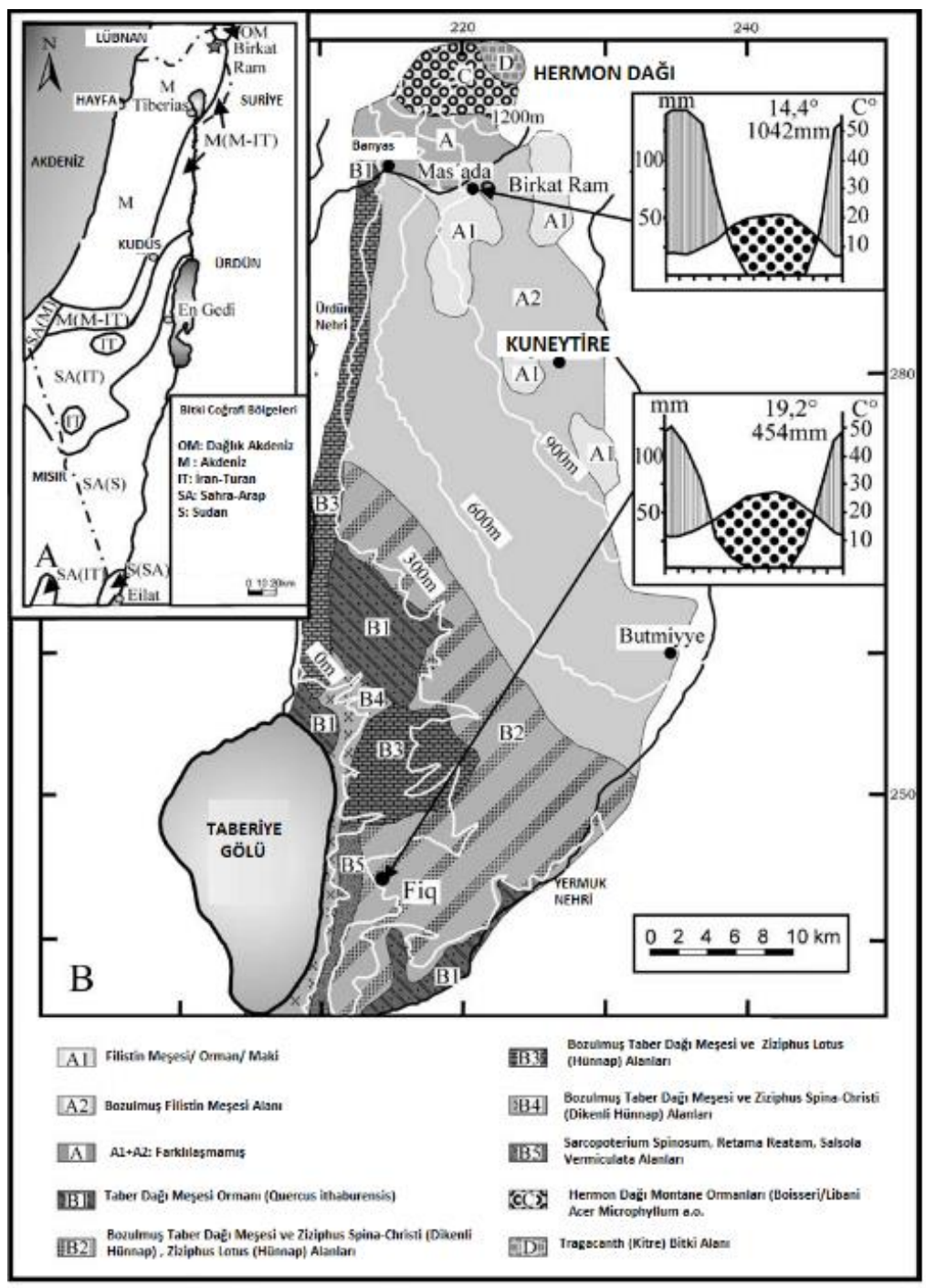

Şekil 5. Golan ve Hermon Dağı'nın bitki örtüsü haritası, (Neumann, Ohlwein, Litt, \& Hense, 2007).

Golan, Akdeniz ikliminin etkilediği bölgede bulunmaktadır. Hâkim rüzgârın bir sonucu olarak Golan tepelerinin batı yamaçlarının aldığı yağış doğu yamaçlardan çok daha fazladır. Golan'ın kuzeyinde yıllık ortalama yağış 1200 mm'ye yaklaşmaktadır. Golan'ın güney kısmı ise yılda yaklaşık 450-500 mm arasında yağmur almaktadır. Burası nispeten kuru iklim özelliği göstermektedir. Golan'ın kuzey ucunda birkaç gün kar yağışı olmaktadır. Hermon Dağı'nın kar örtüsü yılın altı ayı sürmektedir (Neumann, Ohlwein, Litt, \& Hense, 2007). Yağmur mevsimi, Ekim ayından Mayıs'ın başına kadar uzanır ve yağışlar Aralık'tan Şubat'a kadar zirve yapar. Yağış miktarı bölgede kuzeyden güneye doğru önemli ölçüde değiş̧mektedir. En yüksek yağış ülkenin 
kuzey ve orta kesimlerinde görülmektedir (Science Israel, 2021). Golan Tepeleri üzerinde bulunan "Merom" $14^{\circ} \mathrm{C}$ ile İsrail'de bugüne kadar ölçülen en düşük sıcaklık değerine sahiptir (Times of Israel, 2021).

İsrail ve çevresinde dört coğrafi bitki bölgesi bulunmaktadır. Bu bölgeler: (1) Akdeniz, (2) İran-Turan, (3) Sahra-Arap ve (4) Sudan bitki bölgeleridir (Şekil 5). Akdeniz bitki bölgesi en çok zeytinin dağılım alanı ile örtüşmektedir (Şekil 5). Bu bölgede farklı meşe türleri de bulunmaktadır. Hermon ve Golan Tepeleri'ndeki bitki toplulukları çoğunlukla orografi, iklim ve edafik faktörlerden etkilenmiştir. Kuzeydoğudaki bitki örtüsünün bileşimi de yüksek derecede çiftçilik, otlatma ve odunculuk nedeni ile sona ermiştir (Urman , 1985). Bölgede geçmişte yoğun bir şekilde bulunan Lübnan'ın sedirleri, yüzyıllarca gemi yapımı ve tarımsal üretim için arazi açmak içim kesilmiştir. Ayrıca bölgede keçi yetiştiriciliğinin yapılması sedir fidanlarının zarar görmesine neden olmuştur. Bu nedenle bölgede sedir ağaçları büyük ölçüde ortadan kalkmış, yerine meşe toplulukları hâkim olmuştur. Tepeler çoğunlukla makilerle kaplıdır ve yağmur mevsiminde kır çiçekleri bolca açmaktadır (Şekil 5).

\section{Golan Tepeleri'nin Beşerî ve Ekonomik Coğrafyası}

Golan Tepeleri, Haziran 1967'den beri İsrail işgali altında olan Suriye'nin güneybatı köşesinde küçük bir dağlık bölgedir. Hermon Dağı'nın heybetli zirvesi ile stratejik önemi olan askeri bir bölgedir. 2.814 metre yüksekliğindeki Hermon, güney Suriye, güney Lübnan ve kuzey İsrail'in büyük bir kısmına hâkim bir perspektif sağlamaktadır. Nispeten küçük boyutuna rağmen, bölge $1.860 \mathrm{~km}^{2}$ lik bir toplam kara kütlesine sahiptir ve benzersiz arazisi İsrail diğer bölgelerine göre sahip olduğu yüksek konumu ve sağlıklı su kaynakları açısından rakipsizdir. Hermon Dağı, coğrafi özellikleri sayesinde sahip olduğu turizm potansiyeli ile İsrail'de başka hiçbir yerde bulunamayan özelliklere barındırmaktadır (Molony, Stewart ve Hamill, 2009).

Golan Tepeleri'nin verimli tarım arazileri güney kesimindedir; kuzeydeki Hermon Dağı'nın ormanlık ve çalılık alanlarıyla kaplı taşlı etekleri, hayvan yetiştirme için uygun alandır. Golan Tepeleri'ni oluşturan bazaltlar hem İsrail hem de Suriye tarafından evsel ve tarımsal su ihtiyacını karşılamak için kullanılan bölgesel bir akifer görevi görür (Britannica, 2021). İsrail, Suriye'ye ait olan Golan'ı işgal ettiğinden bu zamana bölgenin doğal kaynakları üzerindeki gücünü gittikçe pekiştirmiş ve bölgeye kendi egemenliğindeymiş gibi muamele etmiştir. Bugüne kadar İsrail, Suriye'nin kamu veya özel mülkiyetinin büyük çoğunluğunu kabul etmeyi reddederken, kontrolü altındaki arazinin \%95'inden fazlasını kamulaştırmıştır. İsrail'in Golan'daki doğal kaynak sömürüsü rüzgâr, petrol ve su kaynaklarına el konulmasını da içermektedir. Sürdürülebilir, temiz enerji hedefleri peşinde koşan İsrail, yenilenebilir enerji projeleri başlatarak yetkisini yasadışı bir şekilde Golan'a kadar genişletmeye devam etmektedir. Aynı zamanda, bölgede yaşayan Suriyelilerin doğal kaynaklara ve topraklarına erişimleri engellenirken, esir ekonomilerin yaratılması yoluyla İsrail'e kalıcı enerji bağımlılığına zorlanmaktadır (Marsad, 2021).

İsrail devletinin nüfusu 8.787.045 (Golan Tepeleri ve Doğu Kudüs dahil) kişidir. Golan Tepeleri’nde yaklaşık 22.900 İsrailli yerleşimci yaşarken Doğu Kudüs topraklarında ise yaklaşı 215.900 İsrailli yerleşimci yaşamaktadır (CIA, 2021). İsrail işgalinden önce Golan Tepeleri, çoğu anavatanlarından sürülen ve "Ülke İçinde Yerinden Edilmiş Kişiler" statüsüne sokulan 140.000'den fazla Suriyeliye ev sahipliği yapıyordu (BM Suriye Temsilciliği, 2021). 1967 Savaşı'nın arifesinde, Kuneytire vilayeti 163 köy ve kasaba ve 108 ayrı çiftliğe dağılmış yaklaşık 147.613 kişilik etnik olarak farklı bir nüfusa sahipti. Nüfusun büyük çoğunluğu Arap, çoğunlukla Sünni Müslüman ama küçük Alevi ve Dürzi azınlıklardan oluşuyordu. Ayrıca önemli Çerkez ve Türkmen toplulukları, az sayıda Ermeni ve Kürtlerin yanı sıra 1948 Savaşı'ndan kalan 9,000 Filistinli mülteci vardı. Genellikle tüm bölgeye yayılmış ayrı köylerde ikamet ederken, bu topluluklar özellikle Suriye'nin Fransız işgalinin sona ermesiyle bağımsızlığını kazanmasından sonra uyum içinde yaşadılar. 1967 Savaşı sırasında İsrail, 139 köy ve kasaba ve 61 çiftlikte yaşayan yaklaşık 130.000 nüfuslu bölgenin yaklaşık \% 70'ini ele geçirdi. Bir ay içinde, tüm Golan Tepeleri neredeyse boş kalmıştı. Geri kalanların tümü, bölgenin kuzeybatı köşesinde kümelenmiş yaklaşık 6.000 kişiden oluşan altı köy ve çoğunlukla Kuneytire kasabasında olmak üzere yaklaşık 250 sivildi (Uri, 1983). 1967 İsrail işgalinden bugüne kadar, Golan'ın Suriyeli sakinleri hala evlerine, kasabalarına ve şehirlerine geri dönemiyorlar. Bugün bu Suriyeliler 500.000 kişiyi aşıyor. Bazı Suriyeliler işgal altındaki Suriye Golan'ında kaldı ve yaklaşık 20.000 Suriyeli küçük köylerde yaşamaya devam ediyor. Golan'daki Suriye şehirlerinin, kasabalarının ve köylerinin çoğu, tüm uluslararası kınamalara rağmen 40'n üzerinde yasadışı yerleşim yeri inşa eden İsrail işgal güçleri tarafindan tahrip edildi. İsrail, sadece Suriye Golan'ını işgal etmeye değil, aynı zamanda Golan'ı Suriye halkından ve tarihlerinden arındırmak amacıyla eski kalıntılarını ve jeopolitik atmosferini yok etmeye de devam ediyor (BM Suriye Temsilciliği, 2021).

İsrail yasama organı Knesset, Aralık 1981'de, Golan Tepeleri'ni ilhak eden yasayı onayladı. Bu yasa çıkmadan önce, Golan Tepeleri'nde 28 kırsal topluluk ve yapım aşamasında bir şehir olan Katzrin vardı. İsrail'in 1981 yılına kadar devam eden işgal sürecinde Golan'daki Yahudi nüfusu yaklaşık 5.700 kişiydi. 1981 yılından 1994 
yılına kadar Golan'daki Yahudi nüfusu 5000, 1994 ile 2014 arasındaki yirmi yıl boyunca, Golan'daki Yahudi sakinlerinin sayısı yalnızca yaklaşık 7.000 kişi artmışıtır. 1994 ile 2014 arasındaki dönemde Yahudi olmayan nüfus yaklaşık 11.000 kişi artmıştır. Golan Tepeleri’nde Yahudi olmayan 27.000 kişi ile birlikte yaklaşık 50.000 kişi yaşamaktadır. İsrail'in varlığını güçlendirme konusunda stratejik bir çıkarı olduğu tartışmalı bir bölgede yaklaşık yarım asırlık bir süre içinde 22.000 kişiyi yerleştirmesi, ulusal stratejik hedefleri gerçekleştirmedeki yetersizliğini ve tarihsel başarısızlığını göstermektedir (Israeli Golan, 2021). Golan Tepeleri, Yahudiler için kutsal bir bölge olarak kabul edilmektedir. Bunun nedeni Yahudilere ait kutsal metinlerde birçok kez Golan bölgesine atıfta bulunulması bölgeyi çoğu dindar Yahudi'nin gözünde kutsallaştırmaktadır (Atlıoğlu, 2007).

Golan Tepeleri'nin Türk dış politikasında Kudüs kadar önemli bir yeri olduğu söylenemez. 1967'de İsrail işgal ettiği Golan'la ilgili olarak 1981'de almış olduğu ilhak kararı Türk hükümeti kınamış ancak politik olarak daha ileri gitmekten kaçınmıştır. Bölgede bulunan 22 köyde bin yıldır yaşayan Türkmenlerin haklarının korunması amacıyla en azından "Türkiye itiraz hakkını saklı tutar" şeklinde bir açıklama yapılması yönündeki öneri de zamanın hükümeti tarafından reddedilmiştir. Ayrıca Golan'da 13 köyde yaşayan ve göç etmek zorunda kalan Çerkezlerde Osmanlı İmparatorluğu döneminde bu bölgeye yerleşmişlerdir (Taştekin, 2021).

\section{Golan Tepeleri’nin Jeopolitiği}

Britanya'nın Filistin topraklarından çekilmesi sonrasında 14 Mayıs 1948'de İsrail Devletinin kurulduğu tüm dünyaya ilan edilmiştir. Birleşmiş Milletler, bölge topraklarının Yahudi ve Arap devletlerine bölünmesini öneren bir plan hazırlamıştır. Ancak Arap devletleri BM tarafından hazırlanan bu planı reddetmiştir. İsrail devletinin kurulmasının hemen ardından Arap orduları İsrail'e askeri müdahalede bulunmuşlardır. 1948 yllında yapılan savaşta Arap devletleri yenilmişlerdir. İsrail, 11 Mayıs 1949'da Birleşmiş Milletler üyesi olarak kabul edilmiştir. İsrail, kuruluşundan sonra başta Avrupa ve Ortadoğu'dan olmak üzere önemli sayılda Yahudi göçü alarak nüfusunu artırmıştır. İsrail, 1956, 1967 ve 1973 yıllarında komşusu olan Arap ülkeleri ile üç defa daha savaşmıştır. Bu savaşlardan sonra İsrail, 26 Mart 1979'da Mısır ile 26 Ekim 1994'te ise Ürdün ile barış anlaşmaları yapmışıtır. İsrail, Altı Gün (1967) Savaşı'nda Golan Tepeleri, Batı Şeria ve Gazze Şeridi’ni işgal ederek bu bölgelerin kontrolünü ele geçirmiştir. Filistin ve İsrail, 1990'larda Gazze ve Batı Şeria'da geçici bir Filistin özerk yönetiminin kurulmasını sağlayacak bir dönemi başlatan geçici anlaşmalar imzalamışlardır (Jewish Virtual Library, 2021). İsrail, 2005 yılının Eylül ayında Gazze'den tamamen çekilmiştir (Ynetnews, 2021). İsrail, Akdeniz'in doğu kıyısında bulunan bir Ortadoğu ülkesidir. Kuzeyinde Lübnan ve Suriye, batısında Akdeniz, güneybatısında Sina Yarımadası ve Gazze, doğusunda ise Ürdün devleti bulunmaktadır. İsrail'in komşuları ile sınır uzunlukları şu şekildedir; Gazze Şeridi 59 km, Batı Şeria 278 km, Ürdün 328 km (20 km'si Ölü Deniz içinde), Mısır 206 km, Lübnan 106 km, Suriye 80 km, Akdeniz sahil şeridi ise 273 km'dir (CIA, 2021).

İsrail, "Bereketli Hilal" olarak adlandırılan coğrafyanın Levant (Doğu Akdeniz) bölgesinde yer almaktadır. İsrail, uzun bir kıyı ovasına sahiptir. Orta ve kuzey bölgelerde yaylalar, güneyde ise Necef Çölü'nden oluşan nispeten farklı bir topoğrafik özelliklere sahip olan küçük bir ülkedir (Şekil 6). Kıyı ovası, güneyde yaklaşık $40 \mathrm{~km}$ kadar genişleyen, yaklaşık olarak $185 \mathrm{~km}$ uzunluğa dar bir şerittir. Birçok plaja ev sahipliği yapan kumlu kıyı şeridi, İsrail'in Akdeniz kıyılarını çevrelemektedir. Ülkenin doğusunda verimli tarım arazileri bulunmaktadır (Britannica, 2021). Ülkenin güney bölgesi, Necef Çölü'nden meydana gelirken kuzeydoğusu Şeria Hendeğine açılmaktadır. Ülkenin güneydoğusunda dik yükseltiler dikkat çekerken Lut Gölü'de bu bölgede yer almaktadır. Akdeniz kıyı bölgesinin kuzey bölümü Şaran Ovası adını alırken bu bölge Yafa'dan Karmel Dağı'na kadar uzanmaktadır. Karmel Dağı'nın doğusunda Kişon Irmağı'nın vadisi boyunca Esdradelon Ovası yer almaktadır. Esdradelon Ovası, Taberiye Gölü'ne kadar uzanmaktadır. Ürdün Nehri buradan geçerek deniz seviyesinden $-394 \mathrm{~m}$ aşağıda bulunan Lut Gölü’ne dökülmektedir. Lut Gölü'nün güneybatı sahili İsrail devletine doğu kıyısı ise Ürdün'e aittir. İsrail'in doğu bölgeleri Şamiriye ve Yahudiye Tepeleri'nden Necef Dağı'na kadar uzanan dağlık bir bölgedir. Taberiye Gölü'nün kuzeybatısında bulunan Nyron Dağ 1 İsrail'in en yüksek noktalarından birisidir. Golan Tepeleri, İsrail'in kuzeydoğusunda yer almaktadır (İsrail Dışişleri Bakanlığı, 2021). Suriye'nin güneybatısındaki Golan, 5 Haziran 1967'de İsrail güçleri tarafından işgal edilmiş bir bölgedir. Golan'ın toplam kara kütlesi $1.860 \mathrm{~km}^{2 \prime}$ dir, bu da Suriye'nin toplam alanının yaklaşık \%1'i kadarını oluşturmaktadır. Bu alanın yaklaşık $1.500 \mathrm{~km}^{2}$ si İsrail işgali altında kalmaktadır. Golan bölgesi, İsrail işgalinden önce çoğu anavatanlarından sürülen ve Ülke İçinde Yerinden Edilmiş Kişiler statüsüne sokulan 140.000 'den fazla Suriyeliye ev sahipliği yapmaktaydı (BM Suriye Temsilciliği, 2021). 


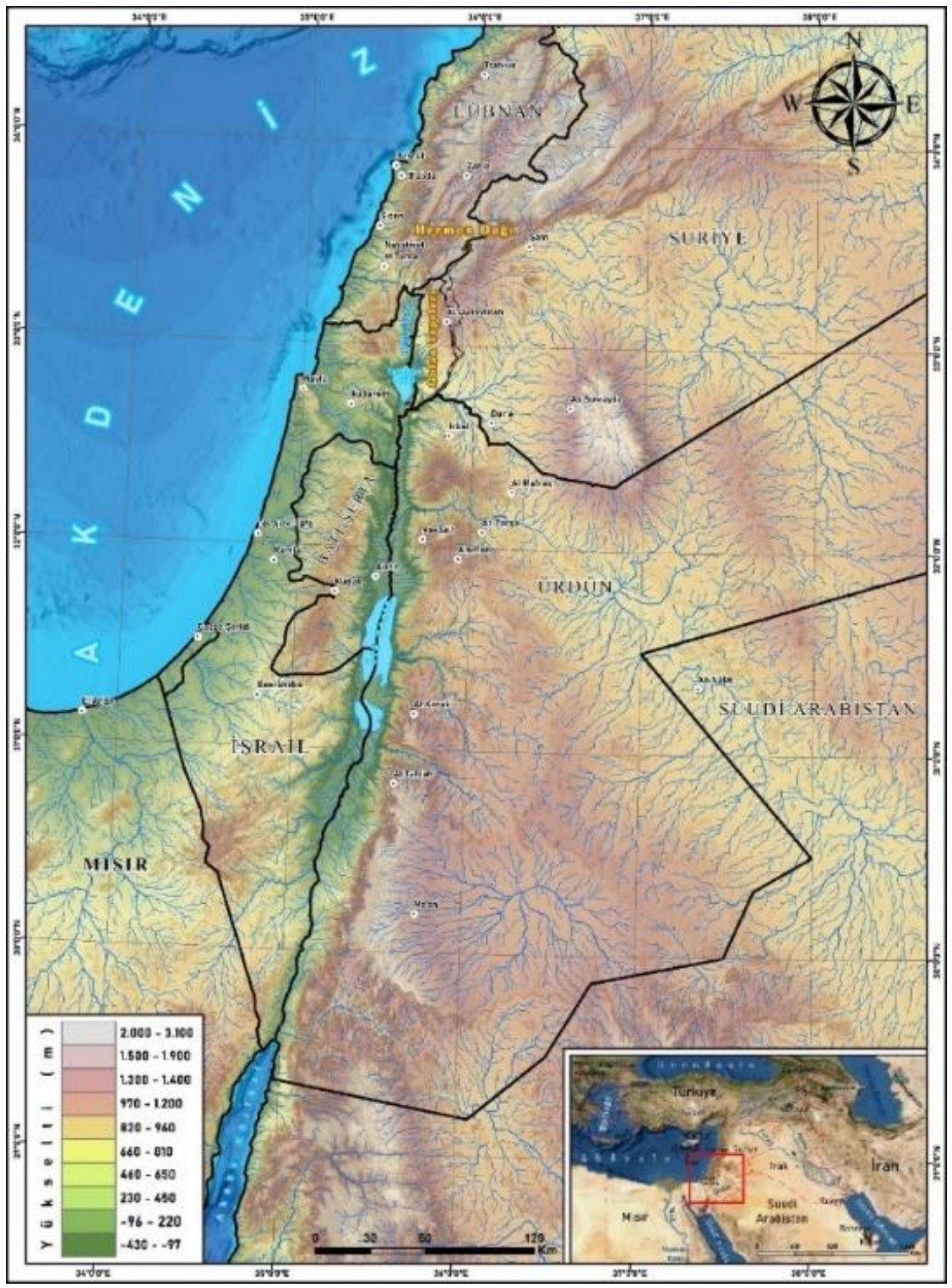

Şekil 6. Golan Tepeleri ve çevre ülkelerin fiziki haritası.

Golan Tepeleri İsrail, Lübnan, Ürdün ve Suriye sınırları arasında bir parmak gibi uzanan stratejik önemde olan bir bölgedir. 1967 yılındaki işgalinden bugüne kadar Golan Tepeleri, İsrail savunma hattının en önemli direnç noktalarından biridir. Golan Tepeleri, Arap ordularının İsrail'i işgal etmesine karşı önemli bir tampon bölgesi olarak görülmektedir. Bölge, İsrail'in sanayi şehirleri olan Hayfa ve Akka'ya çok yakındır (Şekil 7). Bu bölge dost bir komşunun elinde bulunduğunda, askeri açısından önemsiz bir bölgedir. Bununla birlikte, İsrail'in düşmanı bir ülke tarafından kontrol edildiği takdirde, stratejik bir kâbus olma potansiyeline sahiptir (Jewish Virtual Library, 2021). İlk Arap-İsrail Savaşı sırasında (1947-1949), Suriye ordusu Golan'ın topoğrafik avantajlarından yararlanarak İsrail mevzilerine ve yerleşim yerlerine saldırarak önemli kayıplar verdirdi. 1967 yılına kadar Golan Tepeleri'ne egemen olan Suriye, bu tarihe kadar İsrail'in kuzey bölgelerini top ateşine tutmaktaydı. 1967 yılında İsrail'in bu tepeleri ele geçirmesi Suriye'nin askeri hareketlerini kontrol etmek ve güvenli bir tampon bölge oluşturmak için önemliydi. Ayrıca 1949 yılında imzalanan ateşkes anlaşması 1967'ye kadar olan dönem içerisinde farklı zamanlarda bir dizi ateşkes ihlali yaşanmıştır. Bu dönemde Suriye diğer komşu Arap ülkelerinin desteğiyle kaynaklarının çoğunu Golan Tepeleri’nden alan Ürdün Nehri'nden su ihtiyacını karşılamak amacıyla kaynak sularının yönünü değiştirmek için bir plan oluşturdu ve uygulamaya başladı. Bu durum İsrail devleti açısından güvenlikten öte bir sorun olarak ortaya çıkmıştır. 1967'de İsrail, Golan Tepeleri’ni ele geçirmiş ve sonrasında bölgeden çekilmeyeceğini, Golan’ın düşmanları ile bir tampon 
bölge oluşturduğunu ve güvenliğini teminat altına aldığını gerekçe göstermiştir. İsrailliler, Golan ve Sina yarımadasını kontrol ederek kendileri için bir "hayat sahası" oluşturmuşlardır. Golan Tepeleri, Suriye ve İsrail devletleri arasında sadece bir tampon bölge olarak görülmemiştir. 1948 yllından itibaren İsrail, topraklarına katılan her yeni toprak parçası gibi burayı da vatan toprağı olması gerektiğini düşünerek İsrailli yerleşimcilere konut yapmaları için uluslararası hukuku hiçe sayarak izin vermiştir.

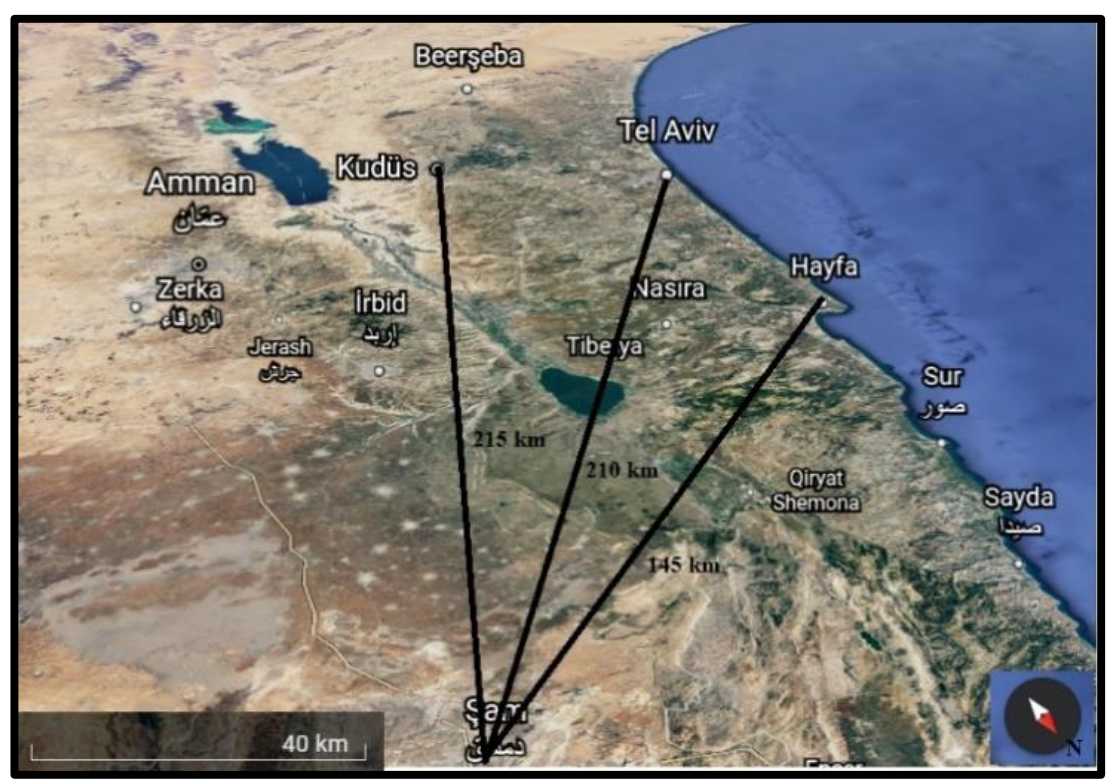

Şekil 7. Golan Tepeleri ve çevresinin uydu görüntüsü, (Google Earth, 2021).

Golan Tepeleri, İsrail'in kurulduğu 14 Mayıs 1948 tarihinden bugüne Ortadoğu'nun stratejik noktalarından birisi olmuştur. Haziran Savaşı olarakta bilinen Altı Gün Savaşı'nda (1967) İsrail ordusunun kazandığı zafer, İsrail milletinin güvenini artırmış ancak yeni sorunların ortaya çıkmasına neden olmuştur. Gazze Şeridi, Batı Şeria ve Golan Tepeleri'nin ele geçirilmesiyle İsrail işgalci bir güç olmuştur. İsrail, işgal ettiği bölgelerde hakimiyeti altında kalan yaklaşık 1 milyon Filistinliyi ise genellikle keyfi bir tutumla yönetmiştir (Cleveland, 2015). Golan Tepeleri su götürmez bir şekilde Suriye'nin ayrılmaz bir parçası olsa da İsrail işgal ettiği bu bölgede o dönem için egemenlik talep etmemiş olmasına rağmen derhal Suriye hukukunu tamamen durdurmuş ve askeri yönetim kurmuştur. Suriye para birimi, İsrail para birimi ile değiştirilmiştir. İsrail plakaları (özel numaralarla da olsa) basılmış, Suriye kimlik kartlarına el konulmuş ve bunların yerini İsrail askeri kimlikleri almıştır. İlk birkaç ayın karmaşasında sıradan insanlar, herhangi bir engel olmaksızın Suriye'ye karadan geçmiş olsalar da Suriye ile "açık köprü" politikasının herhangi bir eşdeğerinden söz etmek mümkün değildir (Tayseer \& Halabi, 1992).

Ekim 1973'te Yom Kippur (Ekim) Savaşı sırasında Suriye, Golan'ı İsrail işgalinden kurtarmaya çalışmıştır. Bu savaşta Suriye, çekilme anlaşmalarından sonra 1967 Altı Gün Savaşı'nda kaybettiği Golan'ın ana şehri ve başkenti Kuneytire'yi içeren bir toprak parçasını yeniden ele geçirmeyi başarmıştır. 1967 Savaşı'ndan sonra Kuneytire'yi terk eden Suriyeliler kurtarılmış evlerine döndüklerinde, şehirdeki her evin, binanın, caminin ve kilisenin İsrail buldozerleri ve dinamitleri tarafından kasıtlı olarak yıkıldığını görünce travma geçirmiş ve şaşkına dönmüşlerdir. BBC ve diğer medya organları tarafından da belgelendiği gibi, şehrin mezarları bile İsrail'in geri çekilmesinden birkaç gün önce İsrailliler tarafından kazılmış ve soyulmuştur. Şehir, İsrail'in sivillere yönelik saldırganlığının canlı kanıtı olarak gösterilmektedir (BM Suriye Temsilciliğ̈i, 2021). Arapİsrail Savaşları sırasında, Golan Tepeleri, bölgede önemli bir savaş cephesiydi. Golan Tepeleri'nin askeri önemi, hâkim yüksekliği, jeopolitik konumu ve Avrupa ile Ortadoğu arasında stratejik bir geçiş noktasıdır. 1973 Arap İsrail Savaşı'nın ardından İsrail ile Suriye arasında 31 Mayıs 1974'te imzalanan bir anlaşma ile Birleşmiş Milletler Gözlem Gücü (UNDOF) kuruldu (UNDOF, 2021).

14 Aralık 1981'de İsrail, işgal altındaki Suriye'ye ait Golan'ı ilhak etmiştir. Bu karara uluslararası toplum, 497 (1981) Sayılı BM Güvenlik Konseyi Kararı ile karşılık vermiştir. Oybirliğiyle alınan bu kararla İsrail'in ilhak kararı "geçersiz ve hükümsüz" sayılmıştır. O dönemde hiçbir ülke bunu meşrulaştırmamıştır. O zamandan beri BM, İsrail işgalinin ve ilhakının yasadışılığını yeniden teyit eden "İşgal Altındaki Golan” başlıklı Genel Kurul kararını her yıl kabul etmektedir. 1991'de Suriye ile İsrail arasındaki barış görüşmeleri, Madrid Konferansı'nda başlamıştır. Ancak İsrail'in Suriye'deki Golan'dan tamamen çekilmeyi reddetmesi nedeniyle müzakereler 
çıkmaza girmiştir. İsrail bugüne kadar BM Güvenlik Konseyi'nin 242 (1967) ve 338 (1973) Say1lı Kararlarını; İşgal Altındaki Suriye Golan'ı da dahil olmak üzere 1967'de işgal edilen tüm Arap topraklarından tamamen çekilme çağnısı yapan ve İsrail'in Golan'ı ilhak etmesinin yasa dışılığını teyit eden 479 Sayılı BM Güvenlik Konseyi Kararını (1981) uygulamayı reddetmektedir (BM Suriye Temsilciliği, 2021).

Golan Tepeleri BM Güvenlik Konseyi'nin 242 ve 338 numaralı kararlarında "İşgal altında bulunan Suriye toprakları" olarak kabul edilmektedir. BM Güvenlik Konseyi'nin 242 Nolu kararına göre "Savaş ile toprak kazanmanın kabul edilemezliği ve bölgedeki her devletin güven içinde yaşayabileceği adil ve kalıcı bir barış için gayret edilmesi gereğini vurgulayarak, Ortadoğu'da kalıcı ve adil bir barışın tesis edilmesini gerektirdiğini" belirtmiştir. Kararda ayrıca "İsrail silahlı kuvvetlerinin; son çatışmada işgal ettiği topraklardan çekilmesi, hak iddialarından veya savaşa yol açabilecek tavırlardan vazgeçilmesi, bölgedeki her ülkenin egemenliği, toprak bütünlüğü ve siyasi bağımsızlığına ve tehdit ve şiddet hareketlerinden uzak şekilde, tanınan sınırları içinde güvenle yaşama hakkına saygı duyulması ve bunların kabul edilmesi, bölgedeki uluslararası sularda denizciliğin serbestliğinin garanti altına alınması, mülteci sorununa adil bir çözüm getirilmesi, askerden arındırılmış bölgelerin kurulması gibi tedbirlerle bölgedeki her devletin bölgesel dokunulmazlı̆̆ ve politik bağımsızlı̆̆ının güvence altına alınmasının gereksinimini onaylar.” şeklinde karar alınmıştır (Birleşmiş Milletler, 2021).

Golan Tepeleri, İsrail'in kurulduğu 14 Mayıs 1948 tarihinden bugüne Ortadoğu coğrafyasının stratejik noktalarından birisi olmuştur. Haziran Savaşı olarakta bilinen Altı Gün Savaşı'nda (1967) İsrail ordusunun kazandığı zafer, İsrail milletinin güvenini artırmış ancak yeni sorunların ortaya çıkmasına neden olmuştur. Gazze Şeridi, Batı Şeria ve Golan Tepeleri'nin ele geçirilmesiyle İsrail işgalci bir güç olmuştur. İsrail hakimiyeti altında kalan 1 milyon Filistinliyi ise genellikle keyfi bir tutumla yönetmiştir. İsrailliler işgal edilmiş toprakların geleceği konusunda tartışılarken, Filistinli mülteci grupları da topraklarını geri almak için adım atmaya başlamışlardı. 1967 Savaşı (Haziran -Altı Gün)'nın en uzun vadeli sonuçlarından birisi de Filistinli direniş gruplarııın önem kazanmasıdır. Arap devletlerinin yurtlarına dönmelerini sağlayamamaları üzerine Filistinli gerilla örgütleri, İsrail'e karşı silaha sarıldılar (Cleveland, 2015).

14 Aralık 1981'de Knesset (İsrail devletinin yasama organı) "Golan Tepeleri Kanunu'nu kabul etti (İsrail Dışişleri Bakanlığı, 2021). Kanunda ilhak terimi kullanılmamış ancak İsrail muhalefeti ve uluslararası kamuoyu tarafindan bu karar bir ilhak olarak değerlendirilmiş̧ir (Wilson ve Donnan, 2012). Bunun üzerine Birleşmiş Milletler Güvenlik Konseyi 17 Aralık 1981 tarihli 497 Nolu kararı verdi. Bu karar "Suriye'nin işgal altındaki Golan Tepeleri'nde, İsrail'in kanunları, yarg1 yetkisi, yönetimi geçersiz ve hükümsüzdür ve uluslararası yasal etkisi yoktur; işgalci güç İsrail'in kararını derhal feshetmesini talep eder" şeklindedir (Birleşmiş Milletler, 2021).

İsrail-Suriye barış görüşmelerinde bu iki devletin sorundan çıkış algıları ile çözüm sağlanması konusundaki iradeleri incelendiğinde tarafların ikircikli ve şartlı çözümle ilgili irade ortaya koydukları görülmektedir. İki devlette kendilerini anlaşma masasına oturtacak iradeye sahip olmalarına karşın bu görüş̧e sürecini devam ettirip istenilen şekilde sonuçlandıracak iradeye sahip olamamışlardır (Sagie, 2021). Suriye'nin barış konusunda bu iradeyi göstermesine karşın tamamen istekli olduğunu söylemek doğru olmayacaktır. Suriye'nin İsrail ile yapılacak barış için olmazsa olmaz şartları bulunmaktaydı. Bu şartların başında İsrail'in 4 Haziran 1967'deki sınırına çekilmesi en başta gelen şartlardandı. Bu konuda İsrail'in kesin bir tavır sergilememesi Suriye'nin barış iradesini olumsuz bir şekilde etkiliyordu. Ayrıca Suriye, barış sonrası İsrail ile ilişkilerine dair çeşitli çekincelere sahiptiler. İlişkilerde İsrail hegemonyasının yaşanabileceği korkusu vardı (Wallid, 1997). Sadık Al-Azm'a göre birtakım çekincelerine rağmen Suriye halkı İsrail ile barışa hazırdı (Al-Azm, 2021). Bu görüşlere karşın Hilal Khashan'ın 1993 ve 1995 yıllarında yapmış olduğu kamuoyu araştırmalarına göre İsrail ile barışa karşı çıkanların oranı 2/3'tür. Khashan'ın 1995 yılında yeniden yaptığı çalışmada Suriye halkının \%17 oranında bir artışla İsrail ile yapılacak bir barışa onay verdikleri görülmektedir (Khashan, 1995).

2020'nin başlarında BAE, Bahreyn ve Sudan örneklerinin ardından 10 Aralık'ta Fas, İsrail Devleti ile ilişkilerin normalleşmesini başlatan en son ülke olmuştur. Kasım 2021'de İsrail Savunma Bakanı Gantz, İsrail'le ilişkilerini normalleştirme anlaşması imzalayan BAE, Bahreyn, Fas ve Umman arasından ilk ziyaretini Fas'a gerçekleştirmiş̧tir. Ziyarette bir mutabakat anlaşması imzalanmıştır. Bu anlaşmaya göre; Anlaşmanın "iki ülke arasındaki savunma ilişkilerinin tanımlanması ve gelecekteki iş birliği için somut bir zemin oluşturduğu, iki ülke arasındaki ilgili savunma kurumlarının karşlıklı istihbarat, endüstriyel iş birliği, askeri eğitim ve daha birçok alanda artırılmış bir iş birliğine ulaşmasına imkân tanıyacağını " belirtilmiştir. İsrail ilk defa bir Arap ülkesi ile böyle bir anlaşma imzalamıştır. İsrail ile diplomatik ilişkinin kurulması ve böyle bir anlaşmanın imzalanması nedeniyle Fas halkı tepki göstermiştir. Filistinliler ise anlaşmaları İsrail ile olan kozlarını aşındıran bir ihanet olarak görmüşlerdir (aljazeera, 2021). Hükümetler, İsrail'le aktif olarak ilgilenirken, sıradan vatandaşlar bu anlaşmalara çok düşük düzeyde destek vermektedir. Ekim 2020'de Arap Barometresi, yaygın 
olarak Abraham Anlaşmaları olarak bilinen bu anlaşmalarla ilgili tutumları ölçmek için altı Arap ülkesinde (Cezayir, Ürdün, Lübnan, Libya, Fas ve Tunus) ulusal düzeyde temsili telefon anketleri gerçekleştirmiş̧tir. Elde edilen verilere göre altı ülkede verilen desteğin çok düşük olduğu görülmektedir. Ankete katılan altı ülkenin beşinde, her on vatandaştan birinden azı, İsrail'in BAE ve Bahreyn ile imzaladığı barış anlaşmalarını desteklemektedir. Destekler Ürdün'de \%3, Libya \%7, Tunus'ta \%8, Fas ve Cezayir'de \%9, Lübnan'da $\% 20$ 'dir. Lübnan bu bölgesel eğilimin ana istisnasıdır. Destek genel olarak \%20 ile düşük kalsa da bölgedeki diğer ülkelerden önemli ölçüde daha yüksektir. Lübnan'da, bu anlaşmalara yönelik tutumlarda mezheplere göre önemli farklı1ıklar vardır; Hıristiyanların yarısı, Dürzilerin sadece \%11'i, Sünnilerin \%6'sı ve Şiilerin \%1'den azı anlaşmaları desteklemektedir. Genel olarak, bu sonuçlar Arap halklarının hükümetlerinin bazı eylemleriyle uyumlu olmadığını göstermektedir (arabbarometer.org, 2021).

Golan Tepeleri'nin yüksekliği İsrail'e, Suriye ordusunun hareketlerini izlemek için mükemmel bir bakış açısı sağlamaktadır (Şekil 2). Golan Tepeleri’nin jeopolitik konumu, verimli topraklar ve su kaynakları, İsrail ve Suriye devletleri için hayati bir öneme sahiptir. İsrail'in kontrolüne geçmeden önce Suriye Golan tepeleri üzerinden İsrail'e taciz atışları yapmıştır. Uluslararası hukuka göre Golan Tepeleri Suriye toprağıdır. Ayrıca Golan Tepelerine bu iki ülke dışında Lübnan ve Ürdün'ünde sınırları bulunmaktadır. Bu tepelere hâkim olmak İsrail'e, yaklaşık 50 kilometre uzaklıkta bulunan Suriye'nin başkenti Şam başta olmak üzere Ürdün'ün başkenti Amman, Lübnan başkenti Beyrut ve Filistin toprakları üzerinde doğal bir kale gibi stratejik hakimiyete imkân vermektedir. Golan Tepeleri’nin en yüksek noktası olan Hermon Dağı'ndan Suriye'nin güneyi ve başkent Şam çok rahat gözlemlenebilmektedir. Golan Tepelerini kontrol eden ülkenin Taberiye Gölü’nü de kontrol etmesi stratejik açıdan ayrıca önemlidir. Golan, İsrail'in güvenliğinin yanı sıra sahip olduğu su kaynakları açısından büyük öneme sahiptir. İsrail, 1967 Savaşı'nda topraklarını 3,5 kat büyütmüştür. Golan Tepeleri, Batı Şeria, Kudüs ve Sina Yarımadası İsrail işgali altına girmiştir. Bu topraklardan özellikle Golan Tepeleri diğer bölgelerden farklı öneme haizdir. Yukarı ve Aşağı Ürdün'de önemli bir stratejik üstünlük sağlayan İsrail, aynı zamanda önemli akiferleri de kontrolü altına almıştır. 1967 Savaşı sonrasında Lübnan ve Suriye'nin havzadaki etkinlikleri azalmıştır. Savaş öncesinde İsrail, havza sularının sadece \%3'üne sahipti. Savaş sonrasında Golan Tepeleri ve Batı Şeria'yı işgal ederek elinde bulundurduğu su oranını \%10'a çıkartmıştır. Sonraki süreçte bu oranı da arttırmıştır (Sınmaz, 2017).

14 Aralık 1981'de İsrail, işgal altındaki Suriye Golan'ı ilhak etti; uluslararası toplum, 497 (1981) Sayılı Güvenlik Konseyi Kararı ile karşıllk verdi. Oybirliğiyle bu hamleyi "geçersiz ve hükümsüz" olarak nitelendiren ve hiçbir ülke bunu meşrulaş̧ırmadı. BM, İsrail işgalinin ve ilhakının yasa dışılığını yeniden teyit eden "İsgal Altındaki Suriye Golan” başlıklı Genel Kurul kararını her yıl kabul etmektedir (BM Suriye Temsilciliği, 2021).

\section{Sonuç}

İsrail, 1967 Altı Gün Savaşı'nda Suriye toprağı olan Golan Tepeleri'ni ele geçirdi. 1967 Savaşı'ndan sonra bölgenin Suriyeli Arap sakinlerinden çoğu savaş sırasında bölgeyi terk etmişlerdir. Savaş sonrasında bir ateşkes hattı kurulmuş ve bölge İsrail ordusunun kontrolü altına girmiştir. İsrail, Golan'ı işgali sonrasında bölgeyi Yahudi yerleşimcilere açmıştır. Suriye, 1973 Yom Kippur Savaşı sırasında hızlı hareket ederek kısa süre içinde Golan Tepelerini geri almıştır. Ancak İsrail ordusunun yedek birliklerinin savaşa hızlı bir şekilde dahil olması ve İsrail ordusunun sahip olduğu tankların teknolojik üstünlüğü savaşın gidişatını değiştirmiş̧ir. İsrail kuvvetleri oransal anlamda bu savaşta diğer savaşlara göre en büyük kaybı vermesine karşın hayati önemde olan geçici bir süre kaybettiği Golan tepelerini tekrar ele geçirmiştir. Her iki ülke de 1974'te ateşkes imzalamıştır. 1974'ten beri ateşkes hattında BM gözlemci gücü bulunmaktadır. İsrail, 1981'de tek taraflı olarak Golan Tepelerini ilhak etmiştir. ABD Trump Yönetimi Mart 2019'da tek taraflı olarak bu ilhakı tanımış olsa da İsrail'in bu kararı uluslararası politik çevreler tarafından tanınmamıştır. İran İslam Devriminden sonra Suriye, İran'ın bölgedeki en önemli müttefiklerinden birisi olmuştur. Lübnan'da Hizbullah'a ve Hamas'a verilen destek İran ve Suriye müttefikliğinin bir sonucudur.

Golan Tepeleri, İsrail açısından beka temeline dayanan farklı gerekçeler ileri sürülerek işgal ve ilhak edilmiştir. Golan Tepeleri tarih boyunca Ortadoğu ile Akdeniz arasında önemli geçiş noktalarından birisi olmuştur. Bu tepelerin kontrolü İsrail'e hem jeostratejik hem de güvenlik açısından önemli avantajlar sağlamaktadır. İsrail devleti açısından Golan Tepeleri'ni önemli kılan nedenlerin başında güvenlik kaygısı ve su kaynakları gelmektedir. Golan, kurak bir bölge için önemli bir su kaynăğdır. İsrail'in, tatlı su ihtiyacının önemli bir kısmını karşılamaktadır. Golan'ın su toplama havzasından gelen sular Ürdün Nehri'ne akmaktadır. Bölgede bulunan arazi volkanik toprak sayesinde çok verimlidir. Bu arazilerde üzüm bağları ve meyve bahçeleri bulunmaktadır. Golan aynı zamanda İsrail'in tek kayak merkezine de ev sahipliği yapmaktadır. Bölgenin su kaynakları açısından önemi, öncelikle verimli bir toprak üzerinde bulunması Golan ve çevresini tarımcılık 
anlamında cazip kılmaktadır. Golan Tepeleri, yenilenebilir enerji bakımından önemli bir konuma sahiptir. Bölgede İsrail'in izin verdiği şirketler tarafindan rüzgâr santralleri kurulmuş ve kurulmaya devam etmektedir. İsrail, işgal ettiği bölgede yatırımlarına devam etmektedir. Enerji ve su alanında çeşitli projelere izin verilmektedir.

Golan Tepelerini kontrolü altında tutan İsrail, bu tepelere sınırı olan Suriye, Lübnan ve Ürdün'e karşı önemli bir askeri üstünlüğe sahiptir. Golan Tepeleri, İsrail ile Suriye arasında yaşanacak muhtemel bir savaşta aşılması zor (tampon) bir mevzi vazifesi görmektedir. İsrail ve Suriye'yi kucaklayan ve güney Lübnan'ı gören kaynak zengini bir bölge, stratejik bir plato olan Golan, BM tarafindan Suriye'nin bir parçası olarak kabul edilmektedir. Golan, İsrail'in güvenliği için çok önemlidir. İsrail, Suriye'deki Esed iktidarını kendi varlığına bir tehdit olarak görmektedir. Bunun yanı sıra Arap Baharı'nın etkisiyle Suriye'de başlayan iç savaş, İsrail'in bölgedeki bir diğer düşmanı İran'ın Suriye'de hakimiyet oluşturmasına imkân sağlamıştır. Ayrıca İran tarafından desteklenen milis grupları da İsrail için önemli bir güvenlik tehdidi oluşturmaktadır. Suriye, işgal altındaki toprağı Golan Tepeleri'ni günümüz şartlarında gerçekleştireceği bir harekâtla geri alabilecek ne askeri ne siyasi irade ve ne de yaptırım gücüne sahiptir. Ancak yaşanan olaylar Suriye'nin İran ve Rusya'ya yakınlaşmasına ve bir ittifakın kurulmasına ortam hazırlamıştır. İsrail, kurulan bölgesel ittifaktan endişe duymaktadır.2011 yılında başlayan Suriye iç savaşı ülkenin toprak bütünlüğünün bozulmasının önünü açmıştır. Zayıf ve yıpranmış bir Suriye, ABD'nin ve İsrail'in Ortadoğu coğrafyasına müdahalesini ve sonuç almasını etkilemektedir. Ancak bölge üzerinde Rusya ve Çin etkisi göz ardı edilmemelidir. Rusya, 2011'den itibaren Suriye'de sahip olduğu askeri varlığıyla Ortadoğu ve Doğu Akdeniz jeopolitiğinde önemli bir etkiye sahiptir. Çin tarafından 'Bir Kuşak, Bir Yol' adıyla sunulan modern İpek Yolu projesi, Çin'in deniz ve karadan Batı'ya ekonomik bir atılım gerçekleştirmesi bölge açısından da önemli bir gelişmedir. İran ve İsrail gibi birbirine düşman olan güçlerle aynı zamanda ilişki kurabilen Çin'in bölge politikalarındaki rolünün göz ardı edilmemesi gerekmektedir. Suriye'de yaşanan iç savaş ABD ve İsrail lehine bir durum olmasına karşın Türkiye'nin aleyhinedir. Suriye iç savaşı Türkiye'nin güvenlik derinliğini tehdit etmektedir. Türkiye'nin en uzun sınırının güvenliği önemli bir tehdit altındadır. ABD ve İsrail'in birlikte Ortadoğu'yu yeniden dizayn etme adımları "Büyük İsrail" hayalinin gerçekleşmesine ortam hazırlamıştır. Suriye'de yaşanan gelişmelerle birlikte değerlendirildiğinde Golan Tepeleri'nin İsrail egemenliğinde olması ile Ortadoğu ve Doğu Akdeniz üzerinde askeri, siyasi ve ekonomik politikalarını gerçekleştirme imkânı vermektedir. Golan Tepeleri, İsrail'e sadece Suriye'ye karşı değil aynı zamanda Irak ve Türkiye'ye karşı izlenecek politikalarda stratejik üstünlük sağlamaktadır. Golan Tepeleri'nde kurulan askeri gözetleme ve radar üslerinin sahip olduğu teknolojik imkanlar binlerce kilometrelik derinliği kontrol etmektedir. Bu durum İsrail'in bir anlamda Türkiye ile komşu olmasi anlamina da gelmektedir.

Golan Tepeleri'ni işgal altında tutan İsrail Devleti'nin barış görüşmelerindeki uzlaşmaz tutumunun yanında barış görüşmelerinde ileri sürdüğü şartlar sorunun çözümünü zorlaştırmaktadır. İsrail'in işgal konusunda siyasi, ekonomik nedenlerin yanında ve dini fanatizmin etkisinden çıkarak Birleşmiş Milletlerin 242 ve 338 sayılı kararlarına uyması gerekmektedir. Günümüzde dünyanın en uzun süreli işgallerinden birisi olan bu sorunun barış içerisinde çözüme kavuşturulması hem bölgesel hem de küresel bir beklentidir. Ancak Golan'daki durumun İsrail'in kendi lehine olması Suriye'nin 1967 öncesindeki saldırılarının güvenlik paranoyası oluşturması iç siyasette kullanılmaktadır. Golan İşgalinin barış içerisinde çözülmesi Ortadoğu'daki huzurun sağlanmasına katkıda bulunacaktır. Ülkede yaşanan iç savaş Suriye'yi siyasi, ekonomik, beşerî ve askeri birçok alanda geriye götürmüştür. Geçen her gün Suriyelilerin Golan Tepelerini geri alma ümitlerini azaltmaktadır. İç savaş sırasında önemli kayıplar yaşayan Suriye'nin, siyasi, ekonomik, teknolojik ve askeri bakımdan güçlü durumda olan İsrail devleti ile başlatacağı politik mücadele yeni cephe açılması demektir.

\section{Kaynaklar}

Agha, Z. (2021). https://www.foreignaffairs.com/articles/israel/2018-11-01/whats-driving-israeli-claimsgolan-heights, Erişim Tarihi: 14.05. 2021

Aji, A. (2021). Trump acceptance of Israeli control of Golan sparks protests. https://apnews.com/article/ba302addc3e24e32b76168c5e0488b4c, Erişim Tarihi: 21.05. 2021

Al-Azm, S. (2021). https://www.nybooks.com/articles/2000/06/15/the-view-from-damascus/ , Erişim Tarihi: 22.11.2021

Aljazeera. (2021). Morocco, Israel sign first-ever defence agreement in Rabat: https://www.aljazeera.com/news/2021/11/24/morocco-israel-sign-first-ever-defence-agreement-in-rabat , Erişim Tarihi: 24.11.2021

Amiran, R. (1970). Ancient Pottery of the Holy Land: From Its Beginnings in the Neolithic Period to the End of the Iron Age. New Brunswick: Rutgers University Press. 
Arabbarometer. (2021). https://www.arabbarometer.org/2020/12/taking-arabs-pulse-on-normalizing-tieswith-israel/ , Erişim Tarihi: 22.11.2021

Atlığlu, Y. (2007). Golan Tepeleri Ve Suriye-İsrail Askeri Güç Dengesi. İstanbul: TASAM.

Bible Charts. (2021). http://www.biblecharts.org/biblelandnotes/Mount\%20Hermon.pdf Erişim Tarihi: 08.05. 2021

Birleşmiş Milletler. (2021). https://unispal.un.org/unispal.nsf/0/7D35E1F729DF491C85256EE700686136, Erişim Tarihi: 24.04.2021

Birleşmiş Milletler. (2021). http://unscr.com/en/resolutions/497, Erişim Tarihi: 25.04.2021

BM Suriye Temsilciliğii. (2021). https://www.un.int/syria/syria/syrian-golan, Erişim Tarihi: 21.11.2021

. (2021). https://www.britannica.com/place/Israel, Erişim Tarihi: 08.05.2021

Britannica. (2021). https://www.britannica.com/place/Golan-Heights , Erişim Tarihi: 03.04.2021

Chesnot, C. (2021). Water disputes undermine peace talks "Drought in the Middle East". https://mondediplo.com/2000/02/08chesnot , Erişim Tarihi: 02.05.2021

CIA. (2021). https://www.cia.gov/the-world-factbook/countries/israel/ , Erişim Tarihi: 28.04.2021

CIA. (2021). https://www.cia.gov/the-world-factbook/countries/syria/\#geography Erişim Tarihi: 08.05. 2021

Cleveland, W. (2015). Modern Ortadoğu Tarihi. İstanbul: Agora Kitaplı̆̆ı.

Daoudy, M. (2008). A missed chance for peace: Israel and Syrı's negotıatıons over the Golan Heights. Journal of International Affairs Editorial Board, 215-234.

Darwish, A. (2021). BBC. Analysis: Middle East water wars: http://news.bbc.co.uk/2/hi/middle_east/2949768.stm, Erişim Tarihi: 02.05. 2021

Google

Earth.

https://earth.google.com/web/@33.11629461,35.4984797,611.70252202a,254617.6520114d,35y,-

141.7436378h,59.9918836t,0r, Erişim Tarihi: 20.11. 2021

Granieri, J. (2015). What is Geopolitics and Why Does It Matter? . Foreign Policy Research Institute, 491504.

Hasanov, A. (2010). Jeopolitik . İstanbul: Babiali Kültür-BKY.

IOLR. (2021). Israel Oceanographic and Limnological Research : http://kinneret.ocean.org.il/dc_lake_general.aspx , Erişim Tarihi: 15.05. 2021

Israeli Golan. (2021). https://www.golancoalition.org/facts/population/ , Erişim Tarihi: 14.05. 2021

İsrail Dışişleri Bakanlığı. (2021). https://embassies.gov.il/istanbul/AboutIsrael/history/Pages/geography-andclimate.aspx , Erişim Tarihi: 08.05.2021

$\begin{array}{lll}\text { İsrail Dişişleri } & \text { Bakanlığı. } & \text { (2021). }\end{array}$ https:/www.mfa.gov.il/mfa/foreignpolicy/peace/guide/pages/golan\%20heights\%20law.aspx , Erişim Tarihi: 25.04.2021

Jewish Virtual Library. (2021). https://www.jewishvirtuallibrary.org/cia-israel-facts-and-figures , Erişim Tarihi: 08.05. 2021

Jewish Virtual Library. (2021). https://www.jewishvirtuallibrary.org/geography-and-geology-of-the-golanheights , Erişim Tarihi: 04.10.2021

Jewish Virtual Library. (2021). Water in Israel: Groundwater Basins: https://www.jewishvirtuallibrary.org/groundwater-basins-in-israel\#5 , Erişim Tarihi: 02.05. 2021

Jewish Virtual Library. (2021). https://www.jewishvirtuallibrary.org/vie-the-golan-heights , Erişim Tarihi: 09.05. 2021

Khashan, H. (1995). The Levant: Yes to Treaties, No to Normalization. Middle East Quarterly, 3-13. https://www.meforum.org/248/the-levant-yes-to-treaties-no-to-normalization ,

Kılıç, S. (2021). İsrail'in Su Güvenliği ve Hizbullah'a Karşı Savaş. https://www.orsam.org.tr/tr/israil-in-suguvenligi-ve-hizbullah-a-karsi-savas/, Erişim Tarihi: 22.11.2021

Lib. Cet. (2021). https://lib.cet.ac.il/pages/item.asp?item=12977 , Erişim Tarihi: 08.05. 2021

Marsad. (2021). https://golan-marsad.org/issues/natural-resource-exploitation/, Erişim Tarihi: 08.05.2021

Marsad. (2021). See Israeli Agricultural Settlement Expansion in the Occupied Syrian Golan During the Syrian Conflict, Al-Marsad,. https:/golan-marsad.org/wp-content/uploads/Settlement-Agricultural-Expansionin-the-Golan-Final-editedCrystal.pdf, Erişim Tarihi: 08.05.2021

Marshall, E. (2002). Israel: Current Issues and Historical Background: Current Issues \& Historical Background. New York: Nova Science Publishers.

Mor, D. (1986). The volcanism of the Golan Heights Ph.D. thesis. Jerusalem: Hebrew Univ.

Mor, D. (1993). A time-table for the levant volcanic province, according to K-Ar dating in the golan heights, Israel. Journal of African Earth Sciences (and the Middle East), 223-234. 
Neumann , F., Ohlwein, C., Litt, T., \& Hense, A. (2007). Holocene vegetation and climate history of the northern Golan heights (Near East). Vegetation History and Archaeobotany, 329-346.

Overland, I. (2015). Future Petroleum Geopolitics: Consequences of Climate Policy and Unconventional Oil and Gas. Norwegian Institute of International Affairs, 3516-3544.

Pamukçu, K. (2000). Su Politikast. İstanbul: Bağlam Yayıncılık.

Popular Mechanics. (2021). https://www.popularmechanics.com/adventure/sports/g430/the-worlds-18strangest-ski-resorts/\#fbIndex2, Erişim Tarihi: 01.05. 2021

Rokach, L. (1980). "Israeli State Terrorism: An Analysis of the Sharett Diaries," . Journal of Palestine Studies, $3-28$.

Sagie, U. (2021). The Israeli-Syrian Dialogue: A One-Way Ticket to Peace? https://www.bakerinstitute.org/research/the-israeli-syrian-dialogue-a-one-way-ticket-to-peace/ , Erişim Tarihi: 20.112021

https://www.science.co.il/weather/Israelclimate.php\#: :text=Israel\%20is\%20located $\% 2 \mathrm{C} \% 20$ between $\% 2029$, summers $\% 20$ and $\% 20$ cool $\% 2 \mathrm{C} \% 2$ 0rainy\%20winters. , Erişim Tarihi: 05.05.2021

Singer, A. (2007). Soils of the Eastern Galilee and the Golan Heights: Basalt and Pyroclastics Derived Soils. The Soils of Israel, 179-206.

Sınmaz, K. (2017). Ortadoğu'da su ve barış “İsrail'in Su Gaspı ve Bölgesel Politikalarl”. İstanbul: İnsamer.

Sutherland, B. (2021). http://news.bbc.co.uk/2/hi/science/nature/2859937.stm, Erişim Tarihi: 02.05. 2021

Taştekin, F. (2021). https://www.al-monitor.com/tr/contents/articles/originals/2019/03/turkey-israel-usa-costof-ankaras-anger-over-golan-heights.html , Erişim Tarihi: 13.05. 2021

Tayseer, M., \& Halabi, U. (1992). Life under Occupation in the Golan Heights. Journal of Palestine Studies, 78-93.

Times of Israel. (2021). https://www.timesofisrael.com/golan-sees-record-low-temperatures-during-storm/ , Erişim Tarihi: 05.05. 2021

UNSC. (1960). United Nations Security Council Official Records, S/4270, S/5084, S/5092, S/5098, S/5401, S/5395, 23 United Nations Security Council Official Records, S/4270, S/5084, S/5092, S/5098, S/5401, S/5395, S75396, S/5401, S/6061, S/6208, S/6243, S/6248. New York: United Nations.

UNSC. (1962). United Nations Security Council Official Records, Letter dated 2 March 1962 from the Representative of Syria to the President of the Security Council S/5084. New York: United Nations.

UNU. (2021). https://archive.unu.edu/unupress/unupbooks/80858e/80858E06.htm Erişim Tarihi: 20.11.2021

Uri, D. (1983). Golan Heights Under Israeli Occupation 1967-1981. Durham: University of Durham, Centre for Middle Eastern and Islamic Studies.

Urman , D. (1985). The Golan-A profile of a region during the Romanand Byzantine periods. . Oxford: BAR International Series.

Varol, M. (2021). İsrail'le İlişkileri 'Normalleştirme' İhaneti. Vuslat.

Wallid, M. (1997). "Fresh Light on the Syrian-Israeli Peace Negotiations". Journal of Palestine Studies, 86.

Waslekar...vd., S. (2013). Water cooperatıon for a secure world focus on the Middle East. Mumbai: Strategic Foresight Group.

Yildız, D. (2009). Golan Tepeleri ve hidro-strateji. Cumhuriyet Strateji Dergisi .

Ynetnews. 2021).https://web.archive.org/web/20051127131754/http://www.ynetnews.com/articles/0,7340,L3136516,00.html, Erişim Tarihi: 21.06.2021

Zieve , T. (2021). This Week In History: The Arab League's three no's. https://www.jpost.com/Features/InThespotlight/This-Week-In-History-The-Arab-Leagues-three-nos , Erişim Tarihi: 21.11.2021.

\section{Etik, Beyan ve Açıklamalar}

\section{Etik Kurul izni ile ilgili;}

च Bu çalışmanın yazar/yazarları, Etik Kurul İznine gerek olmadığını beyan etmektedir.

2. Bu çalışmanın yazar/yazarları, araştırma ve yayın etiği ilkelerine uyduklarını kabul etmektedir.

3. Bu çalışmanın yazar/yazarları kullanmış oldukları resim, şekil, fotoğraf ve benzeri belgelerin kullanımında tüm sorumlulukları kabul etmektedir.

4. Bu çalışmanın benzerlik raporu bulunmaktadır. 